\title{
WHEN CAN LIBERAL STATES AVOID UNWANTED IMMIGRATION? Self-Limited Sovereignty and Guest Worker Recruitment in Switzerland and Germany
}

\author{
By ANTJE ELLERMANN*
}

$\mathrm{T}$

HE recruitment of several million guest workers stands out as one of the most consequential decisions taken by West European governments in the postwar era. Intended as a stopgap measure to fill labor shortages during the economic miracle, guest worker recruitment ultimately brought about the historic transformation of Western Europe's largely homogenous and externally closed nation-states into ethnically diverse countries of mass immigration. Given the scale and permanence of guest worker settlement across recruiting states, it has since become accepted wisdom that in liberal democracies "there is nothing more permanent than temporary foreign workers." Whatever the intentions of their architects, it is argued, guest worker programs are doomed to leave behind a legacy of permanent immigration, attesting to the liberal state's fundamental incapacity to control immigration. ${ }^{2}$

But is it really the case, as so many contend, that liberal states are intrinsically unable to prevent unwanted immigration? This article puts this claim to the test by examining the politics of guest worker recruitment in two major receiving countries: Switzerland and West Germany. Its findings contradict the widespread notion that recruitment in "guest worker countries" was marked by uniformity of policy design

\footnotetext{
*The author acknowledges the generous financial support of the Social Sciences and Humanities Research Council (\#410-2008-0021). For insightful comments on earlier written drafts and constructive discussions about this research, I thank Jim Hollifield, Ellen Immergut, Alan Jacobs, Jeannette Money, Etienne Piguet, and the journal's three anonymous reviewers. I greatly benefited from the presentation of earlier versions at the conferences of the American Political Science Association and the International Studies Association, as well as at the Comparative and Canadian Politics Workshop at the University of British Columbia.

${ }^{1}$ Martin 2001, 1.

${ }^{2}$ Jacoby 2003; Joppke 1998; Martin and Miller 1980; Reichert and Massey 1982.
}

World Politics 65, no. 3 (July 2013), 491-538

Copyright (C) 2013 Trustees of Princeton University

doi: 10.1017/S0043887113000130 
and outcome. Instead, the analysis shows that the two recruitment systems differed in ways that critically impinged on the likelihood of guest worker settlement, thereby qualifying the claim that temporary migrant worker recruitment will inevitably result in permanent immigration. More broadly, the article contests the dominant scholarly argument that the sovereignty of the liberal state is too "self-limited"normatively, legally, and economically — to allow for the exercise of effective immigration control.

One of the most prominent proponents of self-limited sovereignty, Christian Joppke, in his seminal article "Why Liberal States Accept Unwanted Immigration," ${ }^{3}$ attributes guest worker settlement to the judicial and normative constraints facing recruiting states. Residence and family unification rights, he argues, were secured by judicial activism in the postrecruitment period, buttressed by an emerging moral consensus that recruiting countries had certain obligations toward their guest workers. An alternative strand of self-limited sovereignty argument ${ }^{4}$ grounded less in the state's legal and moral liberalism than in its democratic and pluralistic constitution-posits the clout of economic interests as the principal constraint on state autonomy. Gary Freeman's ${ }^{5}$ influential argument that, as a form of "client politics," immigration policy in liberal democracies will reflect the interests of labor-recruiting business lobbies, suggests that employers will either seek to retain workers permanently - in order to lower turnover costs - or endeavor to perpetuate recruitment by "cycling" workers to keep wages down. Collectively, then, these scholars posit that the liberal and pluralistic constitution of democratic states renders them fundamentally ill-suited to operate temporary migrant worker programs and, more broadly, to exercise meaningful immigration control.

A closer look at the politics of recruitment reveals, however, that settlement was not simply beyond the control of policymakers. Switzerland for many years rotated its guest workers free of domestic constraint. While in the West German case legal constraints undoubtedly played an important role in establishing residence rights, ${ }^{6}$ Joppke ar-

\footnotetext{
${ }^{3}$ Joppke 1998.

${ }^{4}$ The term, especially as used by Joppke, typically refers to the legal and moral constraints emanating from the state's "liberalism." Because liberal states are also democracies, I use the term "self-limited sovereignty" more broadly to include sovereignty constraints arising from the mobilization of societal interests.

${ }^{5}$ Freeman 1995.

${ }^{6}$ See also Seol and Skrentny's 2009 analysis of the "negative cases" of labor-importing Japan and Korea, where the absence of normative constraints has been an important factor in preventing the establishment of family unification rights for migrant workers.
} 
gues that judicial reasoning rested on the arbitrariness of policy change, rather than on the substance of settlement controls per se. Similarly, while economic imperatives were important factors in accounting for mass recruitment, they were far from deterministic. At critical points in the operation of their programs, both the West German and the Swiss governments adopted policy decisions that ran counter to business interests.

By comparatively examining the inception and implementation of the Swiss and West German recruitment systems, this article challenges accounts that assert a universal "control incapacity" concerning matters of guest worker settlement. Instead, the analysis exposes significant cross-national variation in states' capacity for immigration control. Specifically, guest worker settlement was more extensive and proceeded at a faster pace in West Germany than in Switzerland. These settlement differences, I contend, cannot be accounted for by divergent judicial and normative policy constraints or by differential economic demand for migrant labor. Rather, variation in the speed and scale of settlement reflects critical, path-dependent differences in policy design between the two countries. Whereas West German officials made no concerted effort to control settlement until the termination of the program, Swiss policy from its inception was marked by state-enforced worker rotation and the prevention of family unification.

What, then, can account for policy differences between two recruitment systems that were both intended to secure a strictly temporary supply of foreign labor? First, I argue, given the enormous challenges involved in operating guest worker systems, past experience with comparable recruitment schemes constituted a critical asset for program design because it conveyed information about likely policy consequences. Accordingly, where past recruitment of migrant workers had resulted in unwanted settlement - as was the case in Switzerland-postwar political elites sought to adopt policy provisions designed to prevent the past from repeating itself. Where past policy failure was absent-the case of West Germany-policymakers were less concerned with preempting settlement.

Second, program design and implementation were shaped not only by the insights and preferences of political elites but also by their capacity to translate these preferences into policy. Specifically, the design of each guest worker system reflected the degree to which policymakers were able to operate autonomously from the cross-cutting societal interests of employer associations (the key champions of recruitment), on the one hand, and the general public (the principal opponent of 
guest worker employment), on the other. To the extent that policymakers had to take account of the demands of either set of actors, they were forced to modify their policy choices. Thus, whereas the West German government was able to pursue recruitment relatively insulated from societal pressures, Swiss policymakers had to accommodate both sets of actors repeatedly and, ironically, in the process managed to devise a system that counteracted settlement by means of rotation.

\section{Revisiting the Guest Worker Debate}

Echoing Hollifield's " "rights-based liberalism" argument, Joppke ${ }^{8}$ contends that the capacity of liberal states to control immigration is constitutionally "self-limited" by the legal process. The settlement of guest workers, he argues, results from judicial activism constraining the decision-making autonomy of policymakers. Joppke rests his argument in part on a landmark 1978 decision by the German Federal Constitutional Court involving the residence rights of an Indian construction worker. The worker had worked in West Germany since 1961, first as a trainee and, after 1967, on the basis of annual work and residence permits. In 1973-just months before the guest worker system was shut down-the local immigration authority refused to renew his annual permit after he had applied for naturalization, arguing that his intention to reside permanently in the Federal Republic was not in the country's interest. The Constitutional Court ruled in favor of the Indian national, arguing that the routine annual renewal of his residence permit had induced "reliance" on the German state and resulted in his integration into German society. ${ }^{9}$

While there is no question that the court's decision curtailed the power of the executive to pursue the return of guest workers, it is critical to note that the rationale underlying the ruling hinged upon the earlier bureaucratic practice of routine renewal of residence permits. In other words, had West German immigration authorities from the very beginning pursued a policy of nonrenewal instead-effectively rotating migrant workers - the legal argument about guest workers' "reliance interest" would not have applied. In order to understand why guest worker recruitment resulted in permanent immigration, then, it is not enough to examine, as Joppke does, the reasons why at a certain point in time a policy reversal was no longer feasible. Instead, we need to ask

\footnotetext{
${ }^{7}$ Hollifield 1992.

${ }^{8}$ Joppke 1998.

${ }^{9}$ Neuman 1990, 49.
} 
why it was that a program that was purportedly intended to provide a temporary labor supply ended up operating in a manner that did not pursue the departure of workers at a time when authorities were legally empowered to do so.

The Swiss case provides a challenge of a different kind. Not only did guest worker settlement unfold significantly more slowly in Switzerland than in West Germany, but it did so in the absence of judicial review. In fact, with its lack of judicialization, ${ }^{10}$ Switzerland closely resembles Joppke's control case of Britain, which illustrates the capacity of a relatively unconstrained state to ward off unwanted immigration. Whatever factors can account for settlement in Switzerland, the answer is unlikely to be the legal process.

Having argued that rights-based arguments cannot fully account for guest worker settlement, we now turn to alternative political economy approaches. Market-based explanations range from globalization arguments that assert that the expansion of international labor markets pushes the control of migrant worker flows beyond the control of individual states, ${ }^{11}$ to domestic explanations that focus on market conditions and the relative power of business. While globalization arguments are ill-suited to accounting for policy variation across countries such as Switzerland and West Germany that occupy comparable positions in the global economy, domestic arguments tend to neglect the role played by national governments in the political economy. Analyses of the guest worker period in particular have tended to adopt economic and structural explanations to account for settlement outcomes. John Bendix, ${ }^{12}$ for instance, has argued that as job stratification comes to be associated with particular populations, over time guest worker recruitment will create a structural gap that can be no longer be filled with native workers. In other words, because guest workers replace, rather than displace, native workers, they remain in their host countries even after economic conditions change. Neo-Marxist scholars, such as Stephen Castles, ${ }^{13}$ have arrived at the same conclusion by pointing to the power of capital over the state. Because employers stand to gain from imported labor not only to meet labor shortages but also more generally to keep wages down, business demand for migrant workers is virtually insatiable. Nevertheless, economic analyses cannot adequately account for policy developments in the two countries. First, recruitment

\footnotetext{
${ }^{10}$ Rothmayr 2001.

${ }^{11}$ Sassen 1996.

12 Bendix 1990.

${ }^{13}$ Castles 1985.
} 
in West Germany commenced at a time when market and employer demand for labor was weak. Second, in both countries, the curtailment of guest worker recruitment took place over the objections of business. The Swiss case is particularly puzzling because the first recruitment controls were introduced at the height of the economic boom and against the staunch opposition of employer associations.

Even political economy accounts that go beyond economic factors have tended to focus exclusively on business interests and have neglected to consider the state as an actor with independent preferences and the institutional power to pursue them. In its most famous formulation, Gary Freeman's ${ }^{14}$ political economy of immigration assertsfollowing James Q. Wilson ${ }^{15}$ - that the benefits of immigration (such as cheap labor) are concentrated and its costs (such as infrastructural bottlenecks) are diffused. As a result, business as the key beneficiary will mobilize in favor of increased immigration, whereas the general public as the main cost bearer will lack the incentives to countermobilize. The ensuing pattern of client politics thus describes the formation of close relationships between business lobbies and policymakers that generate policy outputs dominated by employer interests. Looking at our case studies, however, we find that employer preferences cannot account for the fact that despite the greater political clout of its employer associations, Switzerland not only instituted a rotation system with high employee turnover costs but also capped recruitment in the midst of an economic boom. West German recruitment policy, by contrast, proceeded in a market-driven manner. To understand these differences in guest worker policy, I argue, we need to consider the substantive preferences of policymakers. This is of particular importance when it comes to understanding the adoption of policy measures that ran counter to employer interests, such as the curtailment of recruitment. Before examining these factors in light of the article's theoretical framework, the next section presents empirical evidence in favor of cross-national variation in guest worker settlement.

\section{The Politics of Guest Worker Recruitment: Policy Learning and Elite Insulation}

Guest worker settlement was the unwelcome outcome of recruitment systems intended to facilitate temporary labor migration. Given the economic and political context within which these systems operated,

${ }^{14}$ Freeman 1995.

${ }^{15}$ Wilson 1980. 
was policy failure simply a foregone conclusion? Both rights-oriented and market-oriented analyses have answered this question in the affirmative. James Hollifield in his analysis of postwar economic immigration concludes that "the reasons for policy failures have less to do with the inadequacies of the policies or the government ... than with liberal constraints." 16 Without denying that liberal institutions curtail states' capacity for immigration control, I contend that both rights-based and market-based answers underestimate the extent to which recruitment outcomes are determined by policy design. Settlement is not inevitable if, for instance, residence permits are issued for only short periods and are nonextendable. In other words, settlement can be prevented-or at the very least delayed and scaled down - to the extent to which a rotation system is firmly in place.

While there is no question that rotation systems face greater challenges in liberal than in illiberal regimes (the oil-producing states of the Middle East come to mind), both the historical record and contemporary recruitment programs show that it is possible to manage rotation schemes in liberal contexts. Most notably-and beyond the scope of this analysis-most present-day temporary worker programs operate on the basis of rotation, reflecting a critical process of policy learning from the experiences of the guest worker era. But even in the immediate postwar period, when guest worker recruitment led to large-scale immigrant settlement, the case of Switzerland demonstrates the utility of rotation for inhibiting settlement. As long as Swiss policy was premised on rotation, immigration remained limited. It was only after the principle was watered down in the mid-1960s-importantly, for reasons exogenous to self-limited sovereignty arguments - that large-scale settlement took its course.

\section{Guest Worker Settlement: The Evidence}

Given the constraints of data availability - for the period under study, there are no systematic data on length of guest worker residence- $a$ reasonable proxy for measuring "settlement" is to determine the nonworking proportion of each country's foreign population. Because the residence permits of guest workers were contingent on paid employment, ${ }^{17}$ the nonworking foreign population essentially was made up of family migrants - adult dependents and children-whose presence is broadly accepted as a reliable indicator for the occurrence of settlement.

\footnotetext{
${ }^{16}$ Hollifield 1992, 94.

${ }^{17}$ In Switzerland mandatory unemployment insurance was introduced only in 1984 . While guest workers in Germany did qualify for unemployment benefits, few collected benefits before the oil crisis, given full employment levels prior to 1973 (except for 1966-67).
} 
Accordingly, Figures 1 and 2 show important settlement differences between the two countries. In Switzerland, settlement occurred later and was less extensive than in West Germany. Thus, the number of Switzerland's employed foreigners ${ }^{18}$ - many of whom were seasonal workers-exceeded the size of the year-round total foreign population ${ }^{19}$ until fifteen years into recruitment, when the renegotiation of the 1964 Swiss-Italian recruitment agreement watered down the rotation principle (Figure 1). Yet even after the post-1964 onset of family migration-as indicated by the emergence of a gap between the country's foreign population and the (smaller) number of employed foreignerssettlement did not reach the same proportions as in West Germany. In the mid-1960s, employed workers continued to account for about 80 percent of the country's foreign population (Figure 2). In the mid1970s, when the oil crisis forced many guest workers to leave, the proportion of employed foreigners dropped to 70 percent.

In West Germany, ${ }^{20}$ by contrast, the numerical dominance of employed workers among the country's migrants was short-lived. For about five years - between the start of mass recruitment in 1961 and its slowdown during the 1966-67 recession-employed workers accounted for about 80 percent of the country's foreign population (Figure 2). By the early 1970s, the proportion of working foreigners had dropped to 65 percent, before falling below the 50 percent mark in the postrecruitment period. Twenty years into West German mass recruitment, then, family dependents clearly outnumbered employed guest workers.

To sum up the settlement differences between the two countries, after twenty years of mass recruitment, workers accounted for 80 percent of Switzerland's foreign population but only 46 percent of West Germany's. This variation in the salience of family migration and, thus, immigrant settlement had important long-term implications for the size of each country's foreign population. In 1980-after more than three decades of recruitment - the size of Switzerland's foreign population had tripled. By contrast, and despite the fact that recruitment

\footnotetext{
${ }^{18}$ The Statistical Yearbooks list employed worker figures starting in 1965. For figures prior to 1965, I added the number of seasonal workers, migrants with annual permits, and employed workers with settlement permits. Because the annual (renewable) permit category also includes family dependents, the figures for 1960-64 (when family unification became possible after three years of residence) are somewhat inflated.

${ }^{19}$ Seasonal workers are not included in the total foreign population. Figures for 1951-54 and 1956-59 represent linear estimates, based on official figures for 1950, 1955, and 1960.

${ }^{20}$ Figures for 1956-60 and 1962-66 represent linear estimates, based on official figures for 1955, 1961, and 1967.
} 


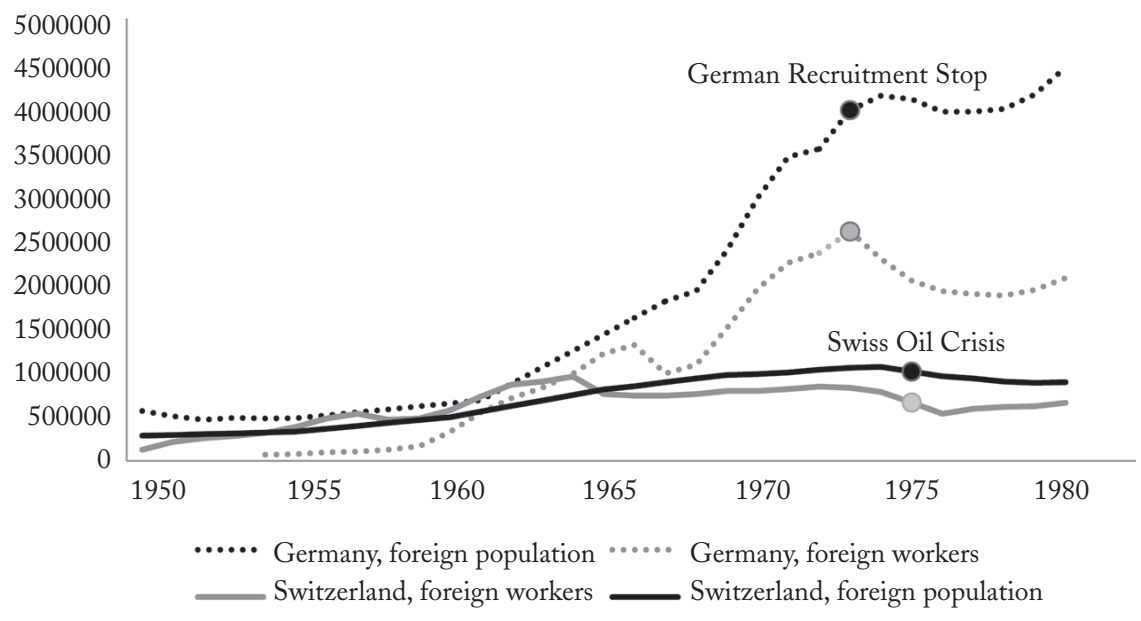

FIGURE 1

Foreign Population and Foreign Workers, Switzerland and Germany Source: Bundesamt für Statistik; Herbert 2001.

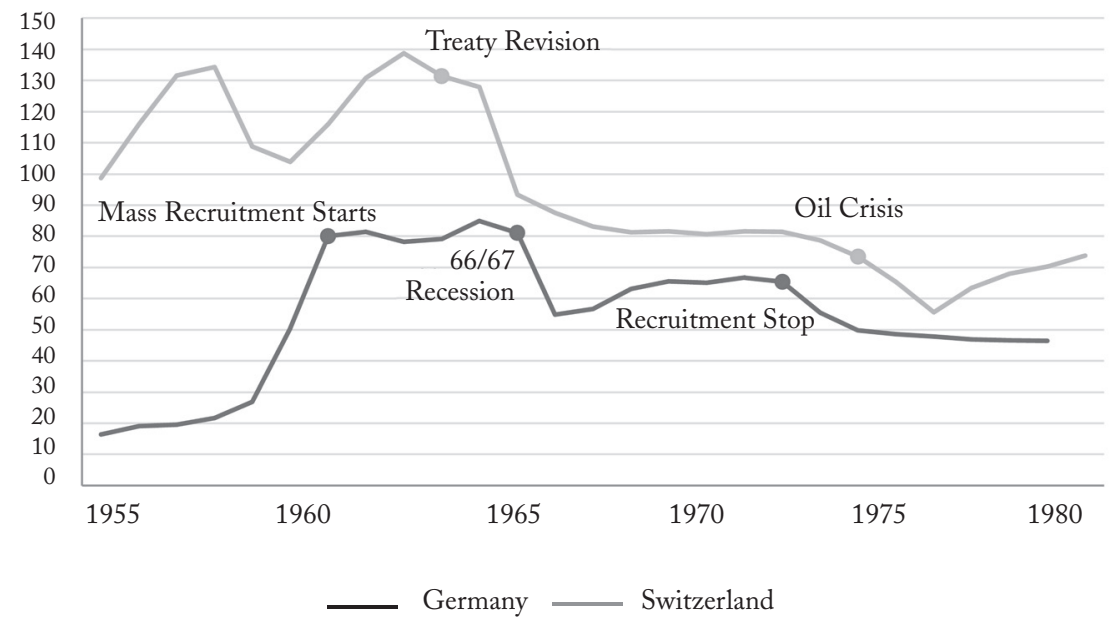

FIGURE 2

Foreign Workers as Percentage of Foreign Population, Germany AND SWITZERLAND

SOURCE: Bundesamt für Statistik; Herbert 2001. 
had gained momentum only a decade later, West Germany's foreign population by 1980 had increased eightfold.

Before further examining the proposed link between these settlement outcomes and the design of guest worker policy, I will present the article's theoretical framework. Two variables, I argue, are of critical importance in accounting for cross-national variation in policy design. First, policy learning matters. Political elites who were able to draw lessons from past foreign worker recruitment were much better positioned to devise policy that counteracted natural settlement processes than were officials who had to proceed by trial and error. As a second key variable, elite insulation from cross-cutting societal interests shaped the degree to which officials were able to act on their preferences when designing and implementing policy.

\section{"Puzzling" and Policy Learning}

When European states designed their postwar guest worker systems, they did so in a context of vast uncertainty. Never before had largescale migrant worker recruitment been undertaken by a body of liberal democracies at a time when migration control was firmly institutionalized. Whereas today's policymakers are fully cognizant of the tension between temporary recruitment and immigration control, the depth of this conflict was far from self-evident to their postwar predecessors. I argue that it was only where policymakers were in a position to "puzzle"21 and draw lessons from the recruitment experiences of others that they were able to minimize unintended policy consequences and pursue policy instruments designed to preempt settlement.

Under what conditions is lesson-based learning likely to occur? As a "detailed cause-and-effect description of a set of actions that government can consider in the light of experience elsewhere," ${ }^{22}$ drawing lessons can occur across time or space. However, unlike today, where the European guest worker experience is frequently referenced in policy discussions across the globe, cross-national policy transfer among postwar European states was not an option, given the close temporal spacing of recruitment across the continent. The possibility of policy learning was thus confined to cases where political actors could draw on prior recruitment experience. Yet not all past experience is equal when it comes to policy learning. Hugh $\mathrm{Heclo}^{23}$ in his pioneering work on policy-making and social learning argues that learning is most likely

\footnotetext{
${ }^{21}$ Heclo 1974.

${ }^{22}$ Rose 1993, 27.

${ }^{23}$ Heclo 1974.
} 
to occur under conditions of negative stimuli-an argument that parallels findings in cognitive psychology about individuals' negativity bias. ${ }^{24}$ Past policy failure matters because it sensitizes policymakers to the possibility of future failure, thus serving, in the words of Peter May, as a "trigger" 25 for rethinking policy design. Based on these arguments, I propose that we are most likely to observe lesson drawing by postwar policymakers where they could reference the experience of past failure, rather than success.

\section{"Powering" and Elite Insulation}

Whether or not political elites are able to draw lessons from past experience has important implications for their policy preferences. Failureinduced learning reduces the uncertainty associated with predicting policy outcomes and lowers the likelihood of unintended consequences. Nonetheless, accounting for the preferences of policymakers gets us only so far in understanding policy output. Decision-making autonomy is a luxury few democratic elites enjoy, and policy choices more often than not constitute compromises between the preferences of a range of state and societal actors. Not only do elite preferences rarely translate directly into policy output but, once adopted, policies frequently change over time, as previously excluded actors pursue change at levels of legislation, regulation, or implementation. In order to account for the policy choices of political elites, in a second step we need to consider the degree to which they are able to pursue their preferences autonomously - in Heclo's ${ }^{26}$ words, we need to examine their ability to "power."

When it comes to making immigration policy, decision-making autonomy is regularly threatened by the mobilization of societal actors. ${ }^{27}$ What distinguishes immigration policy from many other policy fields is the cross-cutting nature of societal influence. Those who make immigration policy regularly find themselves between a rock and a hard place, as the demands of the organized and unorganized publics push in opposing directions. First, the unorganized public usually favors a restrictive stance on questions of admission and stay. ${ }^{28}$ Immigration debates typically touch on highly charged matters of collective identity and self-determination and invite arguments about economic, social,

\footnotetext{
${ }^{24}$ Baumeister et al. 2001; Soroka, 2006.

${ }^{25}$ May 1992, 341.

${ }^{26}$ Heclo 1974.

${ }^{27}$ Hollifield 1992.

${ }^{28}$ Cornelius, Martin, and Hollifield 2004; Freeman 1995; Lahav 2004; Kessler and Freeman 2005.
} 
and cultural competition. ${ }^{29}$ Most recent research on what drives public attitudes on immigration suggests that cultural factors are the primary determinant of public opinion. Accordingly, public opposition to immigration is most strongly driven by concerns about the protection of the national culture. ${ }^{30}$ To the extent that attitudes are shaped by cultural concerns, then, we should expect popular immigration debates to be emotionally charged and essentially protectionist. Policymakers who pursue proposals that seek to liberalize immigration policy—such as the recruitment of guest workers-will thus be most likely to succeed under conditions of popular insulation.

The degree of popular insulation afforded to political elites is shaped by both institutional factors ${ }^{31}$ and the vagaries of political life. Elites who operate in a constitutional context of popular referendums and initiatives, for instance, are particularly vulnerable to public mobilization against immigration, including guest worker recruitment. Similarly, elites in countries with proportional representation electoral systems will-all else equal-enjoy a lower degree of popular insulation than elites in majoritarian electoral systems, because the former are less of a barrier to the success of small, issue-based parties such as antiimmigrant parties. At the same time, variation in popular insulation is also shaped by contingent factors such as unforeseen trigger events, in particular economic recession, that render immigration politically salient and turn inattentive publics into attentive ones.

A second way in which societal influence bears on policymakers is through the lobbying efforts of organized interests. In contrast to restrictionist public opinion, organized interests typically demand a liberalization of immigration policy. To return to Freeman's ${ }^{32}$ work on the political economy of immigration, because the benefits of immigration are concentrated and its costs diffuse, organization is strongest among proimmigration groups, in particular, business associations. As a result, interest-group pressure will typically point in the direction of opening up immigration to foreign workers. However, Freeman's framework ignores one important aspect of interest-group politics. Groups do not compete on an even playing field but are both constrained and empowered by institutions. In particular, corporatist institutions of interest representation not only favor business and labor peak associations over other types of interest groups, ${ }^{33}$ but, depending on the variant of

\footnotetext{
${ }^{29}$ Fetzer 2000; Money 1999.

${ }^{30}$ Sniderman, Haagendorn, and Prior 2004; Hainmueller and Hiscox 2007.

${ }^{31}$ Immergut 1992.

${ }^{32}$ Freeman 1995.

${ }^{33}$ Hollifield 1992.
} 
corporatism, differentially shape the balance of power between business and labor and between the social partners and the state. ${ }^{34}$ Thus, in order to determine how much business insulation policymakers enjoy, we need to consider the power of institutions in shaping the degree to which, first, elites enjoy interest group insulation more generally and, second, business occupies a dominant position in relation to other societal interests.

To sum up, the decision-making autonomy of policymakers depends upon two distinct and independent types of political insulation. First, when it comes to guest worker recruitment, weak popular insulation will curtail the ability of elites to pursue recruitment aggressively. By contrast, if elites operate in a context marked by weak business insulation, policymakers will struggle to rein in recruitment in the face of business opposition. We now turn to our two empirical cases, Switzerland and West Germany. Before delving into the politics of guest worker recruitment, we will briefly examine the rationale underlying this selection of cases.

\section{Case Selection}

Of all labor-importing states of postwar Europe, only three-West Germany, Switzerland, and Austria—constitute guest worker countries in the true sense of the word. Whereas France, Belgium, the Netherlands and, to a lesser extent, Britain also recruited workers from abroad, these countries simultaneously experienced high levels of postcolonial immigration. Because the distinction between guest worker and postcolonial countries is central to Joppke's argument that the normative obligations arising from active recruitment are absent in the case of unsolicited postcolonial immigration, the two cases examined in this article were selected to fall squarely within the guest worker category.

The selection of Switzerland and West Germany among the three guest worker countries seeks to assure maximum variation on the two sets of variables central to my argument. First, the likelihood of policy learning differs across the two states. While both countries experimented with foreign worker recruitment prior to World War I, migration policies and their consequences diverged drastically. Switzerland had in place an open borders system that resulted in large-scale immigrant settlement, accompanied by widespread and lasting societal fears about the country's "overforeignization." Prussia, by contrast, operated a rotation

${ }^{34}$ Katzenstein 1987a. 
system that did not leave behind a legacy of immigration. Given my argument that past policy failure constitutes a necessary condition for elite learning, we would expect the likelihood of policy learning to be significantly higher in Switzerland than in West Germany.

Looking at elite insulation as the second set of variables hypothesized to shape policy design, Switzerland and West Germany vary in terms of the expected popular and business insulation of policymakers. Whereas both countries' recruitment systems were set up at a time when anti-immigrant parties had not (yet) formed-eliminating a potentially powerful source of popular constraint-Swiss policymakers nevertheless distinguish themselves by their intense vulnerability to societal mobilization. Because of the availability of popular referendums and initiatives, Swiss political elites are in a unique position in having to routinely consider the possibility of popular mobilization. Importantly, public opinion can have significant impact on legislation even where referendums do not materialize: "The most successful referendums are those which do not take place. The circles which might have fought the law do not do so because it contains what they want. This is the explanation for the compromise character of a large part of federal legislation; parliament [and the Federal Council do] not make laws in a sovereign way but always under the threat of a referendum." ${ }^{35}$

In stark contrast to Swiss direct democracy, West Germany's political system was designed as a strictly representative democracy, rejecting all elements of direct democracy at the federal level. ${ }^{36}$ Not only did institutions constrain popular mobilization, but public political engagement was further limited by a postwar "detached subject culture" 37 that reflected the experiences of totalitarianism, occupation, and denazification. Baker, Dalton, and Hildebrandt ${ }^{38}$ capture this sense of political detachment in their longitudinal study of informal political discussion- a variable well suited to examining the independent effect of political culture because it is minimally constrained by institutions. In the early 1950s - just before the beginning of guest worker recruitmentinformal political discussion in West Germany was sporadic at best. While today, less than a quarter of the Swiss and German public claim to "never" discuss politics, ${ }^{39}$ in 1953, over 60 percent of the German public admitted to "never" doing so. ${ }^{40}$ By the time mass recruitment

\footnotetext{
${ }^{35}$ Aubert 1978, 48-49.

${ }^{36}$ Kielmansegg 1990; Rohner 2011.

${ }^{37}$ Almond and Verba 1989.

${ }^{38}$ Baker, Dalton, and Hildebrandt 1981.

${ }^{39}$ Janmaat 2006, 384.

${ }^{40}$ Baker, Dalton, and Hildebrandt 1981, 40.
} 
took off in the early 1960s, this proportion, while reduced, remained significant at about 40 percent. We can thus posit that, for both institutional and cultural reasons, postwar policymakers in West Germany enjoyed a much greater degree of insulation from public opinion and popular mobilization than did their Swiss colleagues, who were constrained by both the institution of direct democracy and a civic culture unharmed by Nazism and military defeat.

Turning to the question of business insulation, both Swiss and German political elites operate in political systems in which government and economic interests are tightly integrated and policy-making reflects a process of consensus building. In Germany consensus building is facilitated through the centralized institutions of neocorporatism that allow for the routine representation of peak associations not only on consultative bodies such as ministerial advisory boards but also in key policy-making institutions such as the Federal Labor Agency. ${ }^{41}$ While Swiss economic interests formally participate in the preparliamentary decision-making process (Vernebmlassung) ${ }^{42}$ and are routinely consulted in the policy process, the diffuse nature of the Swiss political system does not allow for the presence of centralized institutions that could ensure a relative balance between labor and business. Whereas Germany's system of "social corporatism" 43 curbs the power of employer associations by guaranteeing labor a seat at the bargaining table, Swiss "liberal corporatism" is marked by a weak central state, weak trade unions, and strong employer associations. ${ }^{44}$ Swiss business has the upper hand over labor not only organizationally-its associations are more numerous, more centralized, and overall better organized $^{45}$ - but its structurally preeminent position is also broadly legitimated by Switzerland's long-standing tradition of market liberalism, which contrasts with Germany's social market economy. Given the "capitalist bias" of the Swiss system, significant trade union influence is usually limited to social, rather than economic, issues. ${ }^{46}$ Finally, not only do employer associations overshadow trade unions on matters of economic and labor-market policy, but their influence frequently also exceeds that of political parties, parliamentary caucuses, and cantons. ${ }^{47}$

\footnotetext{
${ }^{41}$ Kühne 2000; Reutter 2001.

${ }^{42}$ Schmitter Heissler 2000.

${ }^{43}$ Katzenstein 1987a.

${ }^{44}$ Katzenstein 1987a.

${ }^{45}$ Blaas 1992; Kriesi 1982.

${ }^{46}$ Kriesi 1982, 156.

${ }^{47}$ Gruner 1956; Neidhart 1970; Kriesi 1995.
} 
To sum up, Swiss political elites are disproportionately exposed to cross-cutting popular and business pressures on matters of immigration. Taking into account both public opinion and the preferences of employer associations, we would expect Swiss policymakers to be significantly more constrained than their West German colleagues when devising and implementing recruitment policy. We will now turn to the empirical analysis of the two countries, beginning with their historical policy legacies.

\section{Swiss And German Policy Legacies, 1860-1945}

The policy legacies confronting Swiss and West German officials at the end of World War II date back to the late nineteenth century, when the two countries first experienced large-scale labor migration. As classic countries of emigration, neither Switzerland nor Germany could draw on significant domestic labor reserves when their economies expanded dramatically. ${ }^{48}$ But whereas both governments decided to meet labor shortages by recruiting foreign workers, they did so in radically different ways.

\section{Switzerland's Open Borders Policy, 1862-1914}

Starting in 1862 the Swiss government pursued a reciprocal policy of open borders, in keeping with a European era of free movement that began around 1860 and lasted until the outbreak of World War I. ${ }^{49}$ By 1914 Switzerland had entered into bilateral treaties with twenty-one countries and established a reciprocal regime of free movement for migrant workers and their families, ${ }^{50}$ resulting in the settlement of over half a million immigrants- 16 percent of the country's population. ${ }^{51}$

This demographic transformation was to have lasting political repercussions. Already by the turn of the century, rapid immigration had come to trigger periodic xenophobic responses, most famously the 1896 Zurich pogrom against Italian migrants who were feared as economic competitors. It was about this time that a new word that was to become an integral part of Swiss immigration discourse entered the political vocabulary: "overforeignization" (Überfremdung). Between the 1900s and the 1930s, this discourse evolved in two distinct stages. In the first, integrationist stage, elites conceived the threat of overforeignization in

\footnotetext{
${ }^{48}$ Niederberger 1982.

${ }^{49}$ Torpey 2000; Lucassen 2001.

${ }^{50}$ Niederberger 1982.

51 Vuillemeur 1992.
} 
largely political-rather than ethnonational - terms and sought to defuse it through naturalization. ${ }^{52}$ With the outbreak of World War I, the integrative response to overforeignization was replaced by strict immigration controls. Swiss overforeignization discourse now came to be shaped by racial ideas, the spread of nationalism, and the emergence of an ethnocultural conception of the Swiss nation. ${ }^{53}$ In the 1920s xenophobic groups such as the New Helvetian Society-which closely collaborated with federal law enforcement agencies - gained in influence, and the first popular initiatives on matters of immigration were introduced. In 1931 the association of "immigration" and "overforeignization" became firmly embedded in the country's first immigration actwhich remained largely unchanged until 1999-with Article 16 stating that "officials granting foreigner permits need to take into account the spiritual (geistige) and economic interests of the country as well as the degree of overforeignization." 54

\section{Prussia's Forced Rotation Policy, 1890-1914}

While late-nineteenth-century Prussia shared with Switzerland the economic need for migrant labor, the pursuit of foreign labor worked at cross-purposes with Bismarck's policy of "Germanization," which targeted East Prussia's large and fiercely nationalistic Polish population. ${ }^{55}$ This policy was now threatened by the arrival of large numbers of Russian-Polish agricultural workers who, in the words of the daily paper Leipziger Tageblatt, posed the risk of the "Polonization of areas that had already been won over to Germanic customs, culture and language. ${ }^{56}$ Seeking to cater simultaneously to economic lobbies that demanded the recruitment of agricultural workers, on the one hand, and nationalist interests, on the other, Bismarck in 1890 decreed a seasonal agricultural worker policy for Eastern Prussia that was based on forced rotation. In order to prevent settlement, employment was limited to unmarried workers, permits were tied to a given employer, and workers were required to leave at the end of each agricultural season. Bismarck's gamble paid off. Prussia's seasonal agricultural recruitment policy succeeded in accommodating the two dominant, yet contradictory, political impulses of economic liberalism and nationalist closure by means of

${ }^{52}$ Argast 2009.

${ }_{53}^{53}$ Argast 2007.

${ }^{54}$ Emphasis added. Bundesgesetz über Aufenthalt und Niederlassung der Ausländer (ANAG), March 26, 1931.

${ }_{55}^{55}$ Brubaker 1992.

${ }^{56}$ Bade 1982, 128. 
state-enforced rotation. Between 1906 and 1913 - that is, until recruitment was abandoned with the outbreak of World War I-nine out of ten Polish migrant workers left Prussia each fall in order to return in the spring. ${ }^{57}$

\section{Swiss Guest Worker Politics}

After three decades of closed borders, Switzerland once again considered the question of labor recruitment when employer associations warned of worsening labor shortages at the end of World War II. ${ }^{58}$ In October 1945 the Department of Economic Affairs recommended the recruitment of temporary foreign workers and the Federal CouncilSwitzerland's federal executive-authorized employers to commence recruitment. ${ }^{59}$ After a period of informal hiring, the Federal Council in 1948 entered into a bilateral agreement with its preferred labor supplier, Italy. The political process leading up to the conclusion of the recruitment treaty was marked by a broad consensus between Swiss political elites and employer associations. Labor unions, by contrast, initially opposed the agreement out of fear that recruitment would exert downward pressure on native wages. It was only when the Federal Council guaranteed equal work and pay conditions that union leaders acquiesced. ${ }^{60}$

\section{Policy Learning and Guest Worker Rotation, 1948-63}

When the Swiss-Italian agreement was signed, the new recruitment system stood in stark contrast to Switzerland's pre-World War I policy of free movement and settlement. Founded on the principles of reversible migration and the prevention of settlement, migrant workers were now issued only temporary work and residence permits. Seasonal workers played a key role in this rotation-based system: in the first ten years of recruitment, they accounted for two-thirds of all guest workers. ${ }^{61}$ Seasonal permits were valid for a maximum of nine months, with administrative practice oftentimes even more restrictive. Seasonal workers could neither bring in their families nor adjust to nonseasonal status. Annual (nonseasonal) permits, ${ }^{62}$ by contrast, were issued for a

\footnotetext{
${ }^{57}$ Herbert 2001, 25.

${ }^{58}$ Schweizerischer Metall- und Uhrenarbeiterverband, June 6, 1946.

${ }^{59}$ Cerutti 2005

${ }^{60}$ Cerutti 2005; Niederberger 1982.

${ }^{61}$ From 1946 to 1956, seasonal permits accounted for on average 67 percent of all work permits (author's calculations based on Swiss Statistical Yearbooks).

${ }^{62}$ Bewilligung $B$, Jahresaufenthalter.
} 
year at a time and were renewable. ${ }^{63}$ However, annual permit holders were eligible to apply for permanent residence only after ten years of uninterrupted stay. Even for annual permit holders, family unification was close to impossible until the mid-1950s. ${ }^{64}$ Then, starting in 1960, nonseasonal workers could apply for family permits after three years of residence, with applications generally being handled restrictively by immigration authorities. ${ }^{65}$

This radical departure from pre-World War I recruitment policy, I argue, has to be understood as the result of a process of policy learning that entailed a rethinking of the fundamentals of foreign worker recruitment. With the emergence of the new paradigm of overforeignization in response to the country's nineteenth-century legacy of immigrant settlement, Switzerland's second attempt at foreign worker recruitment marked not only the adoption of the new instrument of rotation but also a much more fundamental change in policy goals. ${ }^{66}$ Whereas nineteenth-century migrant worker employment was guided by the paradigm of economic liberalism, recruitment was now constrained by the paradigm of overforeignization.

What were the foundational ideas on which this paradigm was constructed? In its original use at the turn of the century, the term "overforeignization" was applied to the German immigrant community, whose broadly admired economic success had triggered fears on the part of some Swiss intellectuals and politicians that popular admiration for a sizable minority with monarchical ties would dilute the Schweizer Eigenart (unique Swiss characteristics) and weaken native democratic norms. ${ }^{67}$ Before long, the concept came to be used more broadly to express fears that high levels of immigration would weaken Swiss culture and national identity. The first official use of the term dates to 1914, when the Federal Department of Foreign Affairs published a report detailing measures to fight overforeignization. ${ }^{68}$ Significantly, this early use of the term - which assumed a causal relationship between overforeignization and high levels of immigration-left behind a lasting ideational legacy that considered the presence of a large foreign population to be a threat to Switzerland's small native population. Conceptions of the precise nature of this threat continued to evolve. Whereas

${ }^{63}$ Piguet 2006a.

${ }^{64}$ Sheldon 2007.

${ }^{65}$ Neue Zürcher Zeitung, November 21, 1960; Boscardin 1962.

${ }^{66}$ This dynamic closely corresponds to what Peter Hall has termed "third order" policy change. See Hall 1993.

${ }^{67}$ Niederberger 1982.

${ }^{68}$ Kury 2003. 
in the pre-World War I era, overforeignization was mostly conceived in political terms, in subsequent decades ethnocultural-and, during World War II, security - concerns gained in prominence. By the time Switzerland embarked on its postwar recruitment program, the paradigm was well entrenched in both elite and popular discourse.

When in 1946 the Federal Council chose to embrace migrant recruitment as its preferred solution to labor shortages, there had already been a process of policy learning that clearly constrained the parameters of recruitment. Both the Swiss public and the political elite shared the conviction that a recurrence of overforeignization had to be prevented at all costs ${ }^{69}$ and that the achievement of this goal hinged critically on the institution of strict settlement controls. In the words of the Federal Council, which stated first in 1924 and reiterated since, "[W]e do not object to the immigration of foreign nationals, provided they do not settle in Switzerland."70 In 1948, the year in which the SwissItalian agreement was signed, the Federal Council credited the strict immigration controls of the interwar period with "having averted the previous alarmingly high threat of overforeignization" and cautioned that "we need to continue to be vigilant, especially today, where Switzerland once again is immensely attractive to foreigners." Similarly, despite relatively small numbers in the early recruitment period, trade unions warned that "our country is threatened with overforeignization"72 and recommended a long list of "protective measures against overforeignization." ${ }^{73}$ Even employer associations, the unequivocal beneficiaries of recruitment, considered it necessary to pay lip service to the threat of overforeignization and warned of the limits of the "assimilation capacity" of the Swiss people. ${ }^{74}$

While it appears that policymakers did not (yet) attempt to define a numerical threshold of overforeignization, there was a clear consensus about "a causal link between the number of foreigners, and the threat to Swiss identity." 75 Policymakers had consciously turned to the past in search of lessons, as is reflected in the seminal 1964 report of the government-appointed "expert commission on the problem of foreign workers." Detailing the policy lessons learned from the previous open borders policy, the report stated that

\footnotetext{
${ }^{69}$ Neue Zürcher Zeitung, November 13, 1946; Schweizerische Arbeitgeber-Zeitung, June 20, 1947; Cerutti 2005.

${ }^{70}$ Bundesblatt 1924, 517, cited in Mahnig and Piguet 2004, 68, emphasis added.

${ }^{71}$ Cited in Buomberger 2004, 34, author's translation.

${ }^{72}$ Schweizerischer Metall- und Uhrenarbeiterverband 1955, 7.

${ }^{73}$ Schweizerischer Metall- und Uhrenarbeiterverband 1955, 8-9.

${ }^{74}$ Buomberger 2004, 35.

${ }^{75}$ Mahnig and Wimmer 2003, 141.
} 
the dangerous consequences of "spiritual overforeignization" (geistige Überfremdung) were clearly observable before World War I. We didn't recognize this danger at the time, because we succumbed to the illusion that politics and culture could be separated, that we could remain Germans, French, and Italians in a cultural sense, and still remain Swiss. We doubted and even denied the existence of a sense of "Swissness" (Schweizer Eigenart). [. . . As a result, during World War I] the majority of German Swiss supported Germany, while the majority of French Swiss supported the Entente. ${ }^{77}$

The imperative to ward off overforeignization by preventing immigrant settlement, then, gave rise to a recruitment policy that was firmly premised on the rotation principle. BIGA-Switzerland's labor-market bureaucracy-firmly considered the adoption of measures to check long-term residence and family unification as indispensable for the prevention of overforeignization. ${ }^{78}$ In sum, we can understand the establishment of the Swiss guest worker system as an instance of failureinduced policy learning, reflecting a shift in paradigms from economic liberalism to the prevention of overforeignization. The overforeignization paradigm, which originated as a response to the reality of unwanted immigrant settlement prior to World War I, rendered foreign worker recruitment subservient to the goal of settlement control. The pervasive presence of this paradigm allowed for a remarkable degree of recruitment constraint-including the willingness to bear the costs of frequent labor turnover-even in the absence of popular pressure for immigration controls. Faced with the need to balance the disparate goals of economic expansion, on the one hand, and the prevention of overforeignization, on the other, policymakers decided on rotation as the basic instrument of recruitment policy.

\section{Cracks in the System in the Early 1960s}

Shortly after the conclusion of the Swiss-Italian agreement, the Swiss economy sputtered and demand for foreign workers declined. From 1947 to 1950, the number of guest workers dropped precipitously from 125,000 to 63,000 . This brief interlude of economic decline served to legitimize the rotation system as a politically and economically viable policy choice. Conversely, in the mid-1950s, when the onset of the Korean War ushered in a long period of rapid economic growth, recruitment numbers rose steadily, surpassing a quarter of a million in 1957.

\footnotetext{
${ }^{76}$ This term has no English equivalent and is closest in meaning to "the spirit of a person."

${ }^{77}$ Bundesamt für Industrie, Gewerbe und Arbeit 1964, 133.

${ }^{78}$ Bundesamt für Industrie, Gewerbe und Arbeit, March 31, 1953.
} 
Remarkably, with the drastic expansion of the foreign worker population in the 1950s, the rotation system remained in place. The Federal Council continued to balance the goal of economic expansion against concerns about overforeignization, arguing that a market-driven admission policy could extend only "up to the limit demanded by the avoidance of Überfremdung." 79 In 1950 cantons were instructed to issue seasonal permits for three months at a time, after which, depending on economic conditions, they could be revoked without warning. ${ }^{80}$ In a similar vein, throughout the economic boom of the mid-1950s, BIGA issued instructions to issue seasonal-as opposed to annual—work permits whenever possible and to handle requests for family unification restrictively. ${ }^{81}$ Accordingly, several cantons allowed family unification only after ten years of residence. ${ }^{82}$ As a result, throughout the 1940s and 1950s, Switzerland's rotation policy was largely successful in preventing settlement. As late as 1959-more than a decade into recruitment - the vast majority of nonseasonal migrant workers continued to leave the country after two to three years, ${ }^{83}$ while the departure of seasonal workers at the end of each agricultural and construction season was rigorously enforced. Despite the high costs of rotation incurred by employers, annual labor turnover in some firms remained as high as 40 percent. ${ }^{84}$

With the economic boom showing no sign of abating, however, by the late 1950s employers started to seek to avoid the efficiency losses of rotation by retaining nonseasonal workers. By 1960 nearly half of all annual work permits were issued to previous permit holders. ${ }^{85}$ As a result, despite the high hurdle of the ten-year residence requirement, guest workers started to qualify for permanent residency. The numbers were small: in 1960 permanent permits were issued to 6,700 foreigners, representing a mere 6 percent of workers who would have qualified had there been no rotation. ${ }^{86}$ Yet even small numbers mattered, because the very fact of settlement defied the rotation principle. In a similar vein, with the export boom of the early 1960s, labor agencies in heavily recruitment-dependent districts started to defy BIGA's instructions to issue only seasonal, rather than annual, permits. Thus, even though the

\footnotetext{
${ }^{79}$ Geschäftsbericht des Bundestags 1958, 42, cited in Niederberger 1982, 42.

${ }^{80}$ Eidgenössische Fremdenpolizei, December 28, 1950.

${ }^{81}$ Bundesamt für Industrie, Gewerbe und Arbeit, March 31, 1953.

${ }^{82}$ Eidgenössisches Justiz- und Polizeidepartement, December 12, 1956.

${ }^{83}$ Schweizerischer Metall- und Uhrenarbeiterverband 1962.

${ }^{84}$ Buomberger 2004, 18.

${ }^{85}$ Author's calculations based on Swiss Statistical Yearbooks.

${ }^{86}$ Author's calculations based on Swiss Statistical Yearbooks.
} 
relative size of the Swiss seasonal worker population continued to be significant, in the early 1960s seasonal workers no longer accounted for half of foreign workers, but only for just over one-third. ${ }^{87}$

Ironically, at the same time as the advent of immigrant settlement threatened to compromise the viability of the rotation system, guest worker supply started to dry up. Not only had other European countries, including West Germany, since entered into recruitment agreements with Italy, but with the signing of the 1957 Treaty of Rome, Switzerland lost some of its attractiveness as a destination for migrant workers, as free mobility and the harmonization of social insurance schemes were starting to become a reality for members of the European Economic Community. In 1961, aware of Switzerland's predicament, the Italian government demanded the renegotiation of the terms of the 1948 agreement, including reducing the waiting period for family unification to one year and for permanent residence to five years. In the same year, Italy's labor minister, Mario Sullo, caused a public outcry when, during a visit to Switzerland, he denounced the work conditions of Italian workers. This event triggered a new wave of fears that overforeignization had come to threaten the country's political independence - as the employer association's news magazine asked provocatively, "Switzerland - an Italian province?"88 Finally, the year 1961 also marked the beginning of the work of the "expert commission for the study of the problem of foreign labor." Composed largely of civil servants and social scientists, the convening of the commission clearly signaled a recognition on part of the Federal Council that reform was needed. ${ }^{89}$ With the beginning of permanent settlement, it had become progressively more problematic to balance the pursuit of unrestrained economic growth with the imperative to prevent overforeignization.

Meanwhile, in 1962 the Federal Council took a first step toward reform by appealing to employers to restrict the number of employees voluntarily. With no cooperation forthcoming, the government took a rare step of market intervention by instituting a cap (Plafonierungsmassnabme) on the employment of foreign workers. The ceiling measure stipulated that the number of workers employed in 1962 in a given firm was not to be exceeded by the hiring of foreign workers. ${ }^{90}$ Largely drawn up by technocrats within the labor-market bureaucracy,

\footnotetext{
${ }^{87}$ Author's calculations based on Swiss Statistical Yearbooks. See also Bundesamt für Industrie, Gewerbe und Arbeit, March 31, 1953, 1964.

${ }^{88}$ Niederberger 1982, 28.

${ }^{89}$ Niederberger 1982.

${ }^{90}$ Cerutti 2005.
} 
the adoption of this novel policy instrument marked the beginning of a process of trial-and-error policy learning that was motivated by concerns about policy failure. The resultant reform measures emerged from a technocratic, expert-driven process marked by societal insulation. At the same time, the Federal Council faced the opposition of organized business, which denounced the cap as "a grave encroachment on economic freedom. ${ }^{" 1}$ In the end, business secured exemptions for both the agricultural and the hospitality sectors. Similarly, at the cantonal level, many employers were able to negotiate additional firmlevel exemptions. ${ }^{92}$ As a consequence, even though recruitment slowed significantly, the number of new arrivals increased by 4.5 percent by the following year. ${ }^{93}$

What is remarkable about the Federal Council's attempts to rein in recruitment as early as 1962 is the fact that they occurred at a time of unparalleled economic growth and labor demand. No other European guest worker country sought to implement recruitment checks before the economic slowdown of the 1970s. While there were also concerns about economic overheating, the Swiss ceiling measures of the early 1960s are best understood as motivated by the recognition of gradual guest worker settlement and the associated fears of overforeignization. While initially these fears were largely confined to debates within government circles and their social partners, after 1962 they began to surface in the popular arena. The years 1963 to 1965 reflect a sudden rise in media coverage of guest worker recruitment, ${ }^{94}$ framed by the two discourses - "economic necessity of guest worker recruitment" and "overforeignization." 95 Of particular interest here is not only the prominence of the two opposing goals of economic growth and the prevention of overforeignization but also the degree to which the notion of overforeignization was ideologically naturalized: of all articles employing this discourse, over 44 percent did so in a neutral, factual manner. ${ }^{96}$

In 1964, while the Federal Council continued to fine-tune its control measures, the expert commission issued its report. Arguing that Switzerland was "in acute danger of overforeignization" 97 and faced an excess of "foreign penetration," its authors commended a substantial

\footnotetext{
${ }^{91}$ Ständerat, December 8, 1964, 309.

${ }^{92}$ Mahnig and Piguet 2004.

${ }_{93}$ Mahnig and Piguet 2004, 127.

${ }^{94}$ Kamber and Schranz 2000.

${ }^{95}$ In descending order, Niehr 2004, 243.

${ }^{96}$ Niehr 2004, 243.

${ }^{97}$ Bundesamt für Industrie, Gewerbe und Arbeit 1964, 137, author's translation.
} 
reduction in guest worker recruitment. In contending that a "satisfactory" level of economic growth could be achieved with a workforce of half a million nonseasonal permit holders, political elites for the first time sought to quantify a desirable recruitment target. ${ }^{98}$

In the same year, after three years of protracted diplomatic conflict, Switzerland and Italy reached agreement on two critical amendments to the 1948 treaty. First, the waiting period for family unification for workers with annual (nonseasonal) permits was to be lowered from three years to eighteen months. Second, seasonal workers who had worked in Switzerland for five successive seasons were now entitled to apply for annual permits. ${ }^{99}$ From the Federal Council's perspective, these concessions-which, after all, reflected a compromise between the two governments-were necessary to keep recruitment channels open. ${ }^{100}$ Nevertheless, the government realized that the agreement's revision threatened to dilute the fundamental principle of rotation and would not meet with broad popular approval at home. The liberalization of the family unification clause in particular constituted a political liability, given the widely recognized relationship between family unification and settlement. In order to deflect potential conflict, the Federal Council decided to move the provision into an annex to the agreement, thereby exempting it from parliamentary approval. ${ }^{101}$ The agreement was slated to come into effect in November 1964, before ratification by parliament. Little did the government realize that the time of executive-centered decision making was about to come to an end.

\section{The Rise of Populist Politics and the Global Ceiling System OF 1970}

When the Federal Council submitted the revised Swiss-Italian agreement to the legislature, all hell broke loose. For the first time in the postwar era, immigration became the subject of sustained and heated public debate. Much of this debate was tinged with xenophobia, with a newly founded Zurich-based anti-immigrant group, the Swiss Popular Movement against Overforeignization, ${ }^{102}$ pouring oil on the fire. Opponents of the revised agreement portrayed the Federal Council as a puppet of the Italian government and argued that the new agreement would lead to unacceptable levels of overforeignization. ${ }^{103}$ Arguing that

\footnotetext{
${ }^{98}$ Cerutti 2005, 103.

${ }^{99}$ Piguet 2006b.

${ }^{100}$ Cerutti 2005.

101 Cerutti 2005.

${ }^{102}$ Schweizerische Volksbewegung gegen die Überfremdung.

${ }^{103}$ Cerutti 2005.
} 
treaty ratification would carry the risk of popular initiative, the $\mathrm{Na}-$ tional Council-Switzerland's directly elected lower house, which up to this point had shown little interest in recruitment issues-refused to vote on the matter until the government had satisfactorily addressed its concerns. Desperate to secure the National Council's support, the Federal Council promised further recruitment reductions and decreed stricter entry controls at the border. The strategy was successful and in March 1964 the National Council ratified the agreement.

Having averted the threat of legislative veto, the government followed up on its promise to the National Council to further restrict immigration. The "double ceiling" system (doppelte Plafonierung) of 1965 not only limited the overall number of foreign employees in a given firm but also required a 5 percent reduction in a firm's permanent foreign workforce. The measure reflected BIGA's assessment that overforeignization would be most effectively tackled by a reduction of nonseasonal workers. Further strengthened by cutbacks in sectoral exemptions, the double ceiling-unlike previous cap measures - succeeded in reducing the absolute number of arrivals by forty thousand. ${ }^{104}$

Yet despite these administrative successes, the ratified Swiss-Italian agreement continued to serve as a lightning rod for anti-immigrant voices. Just over a year after its ratification, the first "overforeignization initiative" (Überfremdungsinitiative) was submitted by the Democratic Party of the canton Zurich, a small, nationalist party that had gathered sixty thousand signatures. The initiative demanded that the total number of foreign nationals be reduced to 10 percent of the country's resident population at a time when 15 percent of Switzerland's resident population was foreign. ${ }^{105}$ The Federal Council expressed agreement with the basic concerns of the action committee- the threat of the overforeignization of Swiss society-but rejected the initiative's demands as economically irresponsible. The government appealed to the public to reject the initiative and pledged to find new ways of curbing immigration.

Thus, even though the Federal Council was faced with mounting opposition by employers who protested the double ceiling system, under the threat of popular initiative it decreed an additional 5 percent reduction in economic admissions in 1966. Now that the government enjoyed neither business nor popular insulation, it responded to crosscutting societal demands by successively tightening the cap's settings

\footnotetext{
${ }^{104}$ Cerutti 2005, 128.

105 Mahnig and Piguet 2004.
} 
without, however, dismantling the system. After this latest lowering of the ceiling, employer associations, supported by some cantonal governments, aggressively lobbied government for a break from recruitment reductions and argued that the government's control measures were inflicting serious economic harm. The Federal Council, supported by the unions, continued to push ahead with a further 2 percent reduction. Employers, in particular in cantons with expanding, labor-intensive economies, became increasingly restive. Yet the government-still under the threat of the initiative- vowed to plow ahead and announced further reductions: 3 percent by late 1968, followed by a further 2 percent by the end of 1969. After this last announcement, the Democratic Party decided to retract its initiative.

While the initiative's withdrawal marked an important victory for the Federal Council, it did not allow for a permanent retreat into the safety of the executive arena. By late 1968 the country's foreign population share exceeded the previous historical peak of 16 percent. ${ }^{106} \mathrm{Sev}-$ eral months later, a second initiative against overforeignization seized upon this increase and gathered seventy thousand signatures. Organized by the National Action against the Overforeignization of Nation and Home, ${ }^{107}$ and named after its instigator, national councillor James Schwarzenbach, the initiative's demands were even more far-reaching than those of its predecessor. Not only was the proportion of foreign nationals to be capped at 10 percent in any canton other than Geneva, but family unification was to be severely curtailed. The Federal Council-supported by both houses of parliament and the social partnersrejected the initiative, maintaining not only that its demands would cause significant economic harm but that they also violated Switzerland's bilateral agreements and contravened the European Convention of Human Rights.

Three months before the critical vote, the Federal Council decreed a "global ceiling" on immigration (Gesamtplafonierung). The cap was to be based on an annual contingent of new recruits that would be calculated against the expected number of migrant departures. ${ }^{108} \mathrm{Can}-$ tons and employer associations strongly objected to the measure, while trade unions supported it. The government decided to implement the cap over the opposition of employers and cantons and, presenting the global ceiling as the magic bullet for curbing immigration, pledged to keep the system in place even after the popular vote.

\footnotetext{
${ }^{106}$ Mahnig and Piguet 2004.

${ }^{107}$ Nationale Aktion gegen die Überfremdung von Volk und Heimat.

${ }^{108}$ Piguet 2006b.
} 
The vote of June 7, 1970, is considered one of the most significant in postwar Swiss history. The government's stakes were exceedingly high - spanning both economic concerns and matters of high politics in the international arena-but with a turnout of 74 percent, public mobilization also reached a record high. In the words of BIGA director Grübel: "It was a historic vote. Newspapers called it 'a shot across the bows,' 'a unique declaration of no-confidence,' 'a fateful turnaround'! What remains beyond doubt is that for decades no electoral campaign has been fought with a comparable degree of tenacity and passion.... The public attended countless political events in unprecedented numbers. The presence of the mass media even exceeded that observable during major sports events." ${ }^{109}$ To the government's great relief, its gamble had paid off. The initiative was rejected by 54 percent of voters and twenty out of twenty-seven cantons. ${ }^{110}$

The global ceiling system of 1970 - which remained firmly in place until the late 1980s and continues in modified form today - marked the end of two decades of market-driven labor recruitment. As the major losers, employers and those cantons heavily dependent on foreign labor were hardest hit by the new policy regime. By contrast, unions and the public, which had long been supportive of capping immigration, emerged as the winners. Ironically perhaps, so did the Federal Council. Even though the Schwarzenbach Initiative had placed the government in a politically precarious position, it also provided the Federal Council with the leverage necessary to overrule the employer associations as the most powerful player in Switzerland's liberal corporatist system. The global ceiling marks the conclusion of a long series of capping measures pursued by government since the early 1960s. The option of a global ceiling had been debated within BIGA as early as 1965 but was discarded as not politically feasible, given the strength of employer opposition. Thus, had the country not experienced the radical public backlash of the late 1960s, it is doubtful that the Federal Council would have taken on employers and cantons over the institution of a global cap. In the words of BIGA director Grübel, "We had to utilize the increasing political pressure that emanated from public opinion to overcome the resistance of industry." 111 Ironically, then, it was the cross-cutting nature of the societal demands placed on a politically exposed executive that enabled the Federal Council to pursue policy reforms with some degree of autonomy from both sets of actors.

\footnotetext{
${ }^{109}$ Mahnig and Piguet 2004, 78-79.

${ }_{110}$ Passage would have required a double majority.

${ }^{111}$ Cited in Niederberger 1982, 88.
} 
To what extent did the new system succeed in reining in immigration? The measure clearly was successful in regulating the number of annual permits, which, after a short period of stagnation, declined drastically after 1972 (see Figure 3)-well before the oil crisis put an end to unbridled labor demand. In other words, under the global ceiling system the Federal Council was well positioned to control the number of workers subject to permit renewal. Yet while the number of seasonal and annual workers fell precipitously, this was not the case for permanent residents, who were no longer subject to permit renewal. This gradual loss of control over immigrant settlement, I argue, was inextricably tied to the changes brought about by the amended 1964 Swiss-Italian agreement. Looking at the number of workers with settlement permits (Figure 3), we observe a marked increase in its slope in the mid-1960s, reflecting the 1964 lowering of residence requirements, which led to a sudden expansion in the number of foreigners eligible for permanent residency and family unification. Other changes brought about by the treaty revisions took several years to make themselves felt, in particular the option for seasonal workers to adjust their status to that of annual permit holder. Given the presence of a sizable and growing permanent resident population that was no longer subject to numerical control, Switzerland's foreign population share expanded from 17 percent in 1970 to 18.4 percent only three years later.

Returning to the question of self-limited sovereignty, the demise of the Swiss rotation system, which was able to prevent the large-scale settlement of guest workers from the mid-1940s until the early 1960s, cannot be explained by normative or judicial constraints on the Swiss state. Political economy accounts, by contrast, carry some explanatory weight, as is evident in the political clout of employer associations to secure sectoral exemptions from recruitment controls. Yet the reach of economic explanations remains limited. Not only were economic imperatives unable to trump concerns about overforeignization, but the government's ceiling measures ultimately were imposed over the protest of employer associations. I argue instead that the most significant threat to the sovereignty of the Swiss state came not from within but from without. As its European neighbors competed for migrant labor, Switzerland's bargaining position with labor-sending states, most notably Italy, was progressively undercut, resulting in the revision of recruitment treaties that established family unification and settlement rights, thereby clearing the way for large-scale immigrant settlement. 


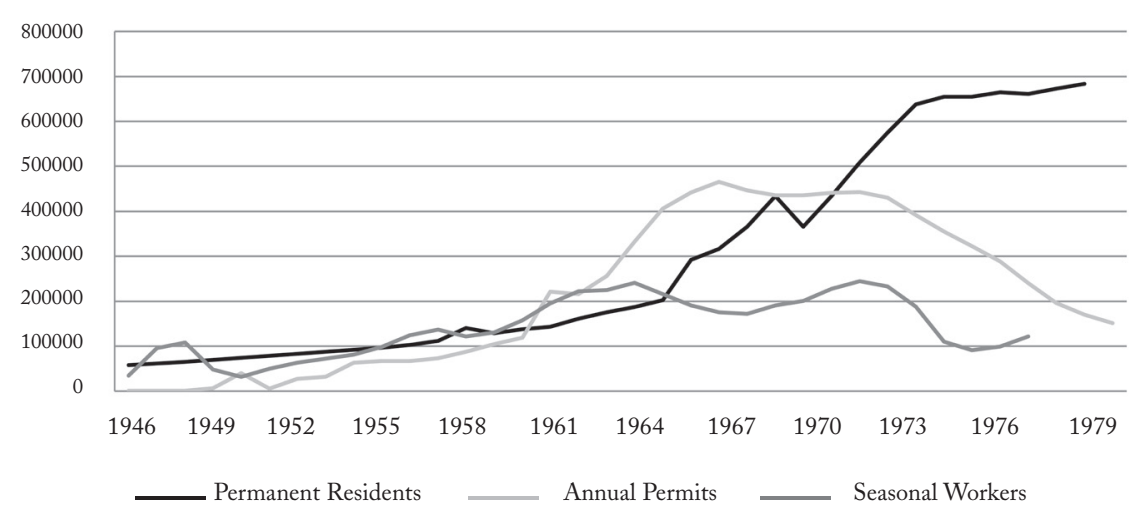

Figure 3

Swiss Guest Worker Permits, 1946-79

SOURCE: Bundesamt für Statistik.

\section{West German Guest Worker Politics}

In West Germany guest worker recruitment had a slow start. In 1953 the cabinet declined Italy's request for a recruitment treaty because refugees from the former Eastern territories were still providing the West German labor market with a steady supply of workers. ${ }^{112}$ When a year later West German diplomatic officials agreed to revisit the issue in the context of trade negotitations, ${ }^{113}$ a deep interministerial rift on the issue surfaced. Both the Ministry of Labor, as the key ministry on matters of recruitment, and the Federal Labor Agency ${ }^{114}$-BIGA's counterpart-were hostile to the idea of foreign worker recruitment. Whereas in Switzerland the biggest stumbling block to recruitment had been concerns about the possibility of immigrant settlement, in the Federal Republic opposition focused on the question of labor-market impact. Speaking before the Bundestag, ${ }^{115}$ Labor Minister Anton Storch stated that his ministry was willing to consider recruitment, but only "should a demand for workers arise that cannot be met from our own reserves"116 and only once all possible rationalization measures had been exhausted. ${ }^{117}$

\footnotetext{
112 Bethlehem 1982; Knortz 2008.

${ }^{113}$ Rhein-Zeitung, December 14, 1954.

${ }^{114}$ Bundesanstalt für Arbeitsvermittlung und Arbeitslosenversicherung.

115 The parliament's lower house.

${ }^{116}$ Deutscher Bundestag, February 17, 1955, 3388.

${ }^{117}$ Frankfurter Rundschau, December 20, 1954; Süddeutsche Zeitung, December 21, 1954.
} 
The Economics and Foreign Affairs Ministries, by contrast, welcomed recruitment as a means of facilitating the country's reintegration into European trade and diplomatic networks. Support for a recruitment treaty was spearheaded by Economics Minister Ludwig Erhard, the father of the "economic miracle," who argued that Italy's growing trade deficit posed a threat to market liberalization and constituted a danger to the process of European economic cooperation. The only remedy to this dilemma, he asserted, was for West Germany to recruit Italian workers. For both ministries, the recruitment of Italian workers was not a question of if, but rather of when.

By 1955 labor shortages intensified in low-skilled industrial sectors and in agriculture, and the employers' peak association ${ }^{118}$ started to throw its weight behind calls for migrant recruitment. ${ }^{119} \mathrm{With}$ declining unemployment, the Federation of Trade Unions ${ }^{120}$ acquiesced to migrant recruitment on the condition that foreign workers would receive both equal pay and benefits and-in light of the continuing housing shortage-employer-provided accommodation. ${ }^{121}$ In a cabinet meeting in October, Chancellor Konrad Adenauer contended that a recruitment agreement with Italy would allow the Federal Republic to achieve its central economic and diplomatic goals simultaneously. He requested policy blueprints from the Economics and Labor Ministries, ${ }^{122}$ but, owing to turf competition and conceptual disagreement, neither report was deemed a suitable framework for recruitment policy. ${ }^{123}$ By now, however, the speed of bilateral negotiations had overtaken the pace of interministerial discussions.

\section{Recruitment without Settlement Controls, 1955-73}

When in December 1955, after nearly two years of negotiations, the German-Italian agreement was signed, West German officials concurred with their Swiss colleagues that guest worker recruitment was to be a purely temporary labor-market measure. Where they differed, however, was in their assessment of how to ensure the temporariness of migration. There is no evidence that West German policymakers seriously grappled with the question of settlement prevention. Instead, they put great faith in the self-regulatory power of the market and assumed that foreign workers would voluntarily return to their home

\footnotetext{
${ }^{118}$ Bundesvereinigung der Deutschen Arbeitgeberverbände.

${ }^{119}$ Knortz 2008.

${ }^{120}$ Deutscher Gewerkschaftsbund.

${ }^{121}$ Neue Zürcher Zeitung, December 22, 1955.

122 Knortz 2008.

${ }^{123}$ Knortz 2008.
} 
countries should labor demand slow down. Looking at archival and newspaper records from the 1950s, it appears that the possibility that migrant workers might chose to remain was simply not entertained. This relative lack of concern with the question of settlement, I argue, gave rise to two critical policy differences between the two recruitment systems.

First, whereas the Swiss system included a large seasonal worker component, the overwhelming majority of guest workers in West Germany held renewable, annual permits. Second, because Swiss policymakers were fully cognizant of the link between family unification and permanent settlement, they had placed tight restrictions on the issuance of family visas. In the Federal Republic, by contrast, there was a broad consensus that family unification was to be tolerated. ${ }^{124}$ Many officials considered family migration even desirable, either for economic reasons - to lower the cost of worker turnover-or for reasons of public order and the preservation of family values. ${ }^{125}$ Accordingly, authorities accepted the recruitment of relatives and not infrequently hired married couples, thereby establishing recruitment practices that clearly facilitated and accelerated family immigration. Thus, by 1971 one-third of all workers hired through the official recruitment commission were relatives of already employed guest workers, ${ }^{126}$ with overall numbers likely much higher. Similarly, and in stark contrast to Swiss practice, the immigration of family dependents was largely handled in a laissezfaire manner. As a result, by 1968 - thirteen years into recruitment-a staggering 30 percent of the West German adult foreign population had arrived as dependent spouses, rather than as recruits. In Switzerland, by contrast, in the same year-and after a significantly longer recruitment period of twenty years - only 17 percent of adult migrants had entered as dependents. ${ }^{127}$ Finally, looking at the migration of children, Gonzalez-Ferrer ${ }^{128}$ estimates that close to one-fifth of all guest workers arrived jointly with their spouse and at least one child.

To the extent that guest workers were able to bring their families, the incentives to remain were that much greater. In West Germany settlement processes were further facilitated by a highly permissive permit practice that entailed not only routine renewal of annual permits but also the issuing of indefinite permits. ${ }^{129}$ As a result, by 1968 - thirteen

\footnotetext{
${ }^{124}$ Pagenstecher 1993.

${ }_{125}$ Frankfurter Rundschau, February 27, 1961.

${ }^{126}$ Pagenstecher 1993.

${ }^{127}$ Calculations by author, based on Pagenstecher 1993, 16, and Tagesanzeiger, March 1970.

${ }^{128}$ Gonzalez-Ferrer 2007.

${ }^{129}$ Deutscher Bundestag, February 21, 1973.
} 
years into recruitment -57 percent of male guest workers had resided in Germany for longer than four years. ${ }^{130}$ In Switzerland, by contrast, eleven years into (formal) recruitment, only 25 percent of guest workers had been in the country for longer than three years. ${ }^{131}$

How can we account for these cross-national differences? Why was Swiss recruitment policy guided by rotation and marked by detailed administrative regulations to prevent settlement, while in West Germany little attention appears to have been paid to the possibility of permanent immigration? I argue that the absence of failure-induced policy learning shaped West German recruitment policy in two important ways. First, the relative naïveté of West German policymakers about the likelihood of immigrant settlement reflects the informational properties of policy learning. Switzerland's legacy of past settlement provided both elites and the public with a basic understanding that, over time, uncontrolled temporary migration will result in permanent immigration. Second, this broad recognition of the long-term consequences of laissez-faire recruitment served to legitimate the concerns of those who sought to impose strict settlement controls. The significance of this latter point becomes apparent when we consider one of the only two instances ${ }^{132}$ where the West German cabinet considered the question of immigration control: the negotiation of the 1964 GermanTurkish recruitment agreement.

Like comparable agreements with Greece, Spain, and Portugal that West Germany ratified in the early 1960s, the 1964 German-Turkish agreement was a response to the heightened labor shortages after the Berlin Wall had cut off the East-West migration of German workers. Unlike the German-Italian agreement, however, it was entered into at a time when interior officials - charged with the mandate of immigration control - had become aware that a process of immigrant settlement was under way. Not only did the steady inflow of migrant workers show no sign of abating - in 1964, the number of foreign workers passed the one million mark-but it had become clear that family unification and prolonged residence were widespread. As a result, the Interior Ministry insisted that Turkish labor migration be strictly time limited and without the option of family migration. The Labor and Economics Ministries strongly opposed these restrictions. The Foreign Affairs Ministry

${ }^{130}$ Auswärtiges Amt, March 20, 1972.

${ }^{131}$ Schweizerischer Metall- und Uhrenarbeiterverband 1962; Buomberger 2004, 19.

${ }^{132}$ The second instance was the attempt of the federal and Land interior ministers to impose a three-year stay limit on guest workers during negotiations of the 1965 immigration law. Again, opposition by the Economics and Foreign Affairs Ministry led to the rejection of rotation. See Triadafilopoulos and Schönwälder 2006. 
in 1961 brokered an agreement that limited employment to two years and did not include provisions for family unification. ${ }^{133}$ Yet less than a year later, the Economics Ministry and the Confederation of German Employers demanded that the two-year clause be dropped. The Interior Ministry was prepared to support this revision in exchange for an amendment that explicitly ruled out the possibility of family unification. The Turkish government rejected this proposal, which would have denied its nationals the family unification rights available to all other guest workers. Other ministries concurred and warned that the proposed family unification amendment would set back the government's efforts to enhance West Germany's image abroad. ${ }^{134}$ Realizing its political isolation, the Interior Ministry conceded and the revised German-Turkish agreement of 1964 included neither a maximum stay clause nor special restrictions on family unification.

Even though interior officials began to recognize the long-term consequences of guest worker recruitment as early as 1961, the cabinet decided to subordinate emerging anxieties about immigration control to labor-market and foreign policy imperatives, leaving the Interior Ministry isolated. Thus, whereas in Switzerland the fear of overforeignization loomed large from the beginning and motivated the construction of a system that not only assumed, but also enforced, rotation, there was no comparable dynamic in the Federal Republic. When interior officials started to warn of the danger of permanent settlement, the significance of these concerns remained unrecognized. As a result of the absence of a unifying paradigm of migration control, the concerns of interior officials did not carry sufficient weight to serve as a counterbalance to economic and diplomatic policy imperatives. Finally, the making of recruitment policy continued to take place in a context of popular insulation. Neither parliament nor the general public at the time paid much attention to questions of recruitment, and, as a result, there were no countervailing popular pressures that could have buttressed the Interior Ministry's calls for stricter recruitment controls.

\section{The Recession of 1966 and the Failure of \\ Popular Mobilization}

Two years later the era of popular insulation threatened to come to an end. The first politicization of guest worker recruitment was trig-

${ }^{133}$ Hunn 2005.

${ }^{134}$ Triadafilopoulos and Schönwälder 2006. 
gered by an article published in March 1966 in the mass tabloid Bild titled, "Are guestworkers harder working than Germans?"135 The article reported on a conference organized by the Confederation of German Employers which, ironically, was intended to shore up support for continued guest worker employment. This provocative challenge to the German work ethic sparked the Federal Republic's first major guest worker-related protests, as thousands of employees in the Southwest of the country went on strike. In some firms, fights broke out between native and foreign workers. Even though the media widely condemned the Bild article and worker protests quickly died down in response to trade union appeals, the event came to mark the beginning of the Federal Republic's first sustained public debate on migrant recruitment, including the social and fiscal implications of immigrant settlement. For the first time, recruitment was no longer exclusively framed as an issue of labor-market policy but instead came to be redefined as a broader issue of social and integration policy.

The debate was not without impact in governmental circles. The Interior Ministry took this opportunity to argue that West Germany as a "country of nonimmigration" had "quite limited absorption and assimilation capacity" 136 and demanded that residence permits and family unification be made contingent on occupational and behavioral assimilation. Even the Economics Ministry concluded that whereas the recruitment system continued to be economically beneficial, its noneconomic impacts-including the "irrational reaction of the German public"-spoke in favor of "stabilizing," rather than increasing, recruitment. ${ }^{137}$ Instead of proposing measures to achieve this "stabilization," however, the ministry maintained that domestic rationalization, combined with modernization processes abroad, would automatically lead to a decrease in immigration.

Meanwhile, West Germany experienced its first economic downturn. Even though unemployment remained modest by today's standards, the economic slowdown was widely perceived as a threat to the economic miracle that had come to define the young republic. Guest workers now were seen as competitors, rather than as facilitators of economic growth. In a 1967 public opinion survey, 62 percent of respondents supported laying off employees on the basis of immigration status, rather than on the basis of work performance. ${ }^{138}$ Popular calls

\footnotetext{
135 Bildzeitung, March 31, 1966.

${ }^{136}$ Hunn 2005, 184.

${ }^{137}$ Hunn 2005, 182.

${ }^{138}$ Allensbacher Institut, February 1966, cited in Schönwälder 2001, 174.
} 
for the departure of guest workers were often tinged with xenophobia ("Foreigners out!"), and for the first time political elites felt the need to reassure the public that, in contrast to Switzerland's much higher proportion of foreign nationals, West Germany was not threatened by overforeignization. ${ }^{139}$

During the downturn, many guest workers decided to leave Germany. This process of return migration was not the result of coercive government action, however. In fact, unlike in Switzerland, the vast majority of workers - that is, all who had been employed for a minimum of six months - qualified for unemployment benefits and were entitled to reside in West Germany for the duration of these benefits. Many, however, chose to receive their benefits in their home countries, and, as a result, around half a million guest workers-one-third of foreign workers - chose to leave. ${ }^{140}$

The economic downturn proved to be short-lived, and recruitment resumed quickly. Despite its brevity, the recession of 1966-67 had important political implications. First, it reassured many observers that guest worker recruitment was still responsive to labor-market needs, even in the absence of forced rotation. Second, the recession put a premature end to the immigration debate that had just gotten under way in the popular arena. Unlike in Switzerland, where the institution of the popular referendum not only provided a low threshold for public mobilization but also forced policymakers to be responsive to the antiimmigrant agendas of popular initiatives, no equivalent channels existed in West Germany. The only potential mobilizing institution was the far-right National Democratic Party (NDP), which did see important electoral successes during this period. However, the NDP did not campaign on an anti-immigrant platform but focused instead on the much more radical demands of reestablishing the German Reich. ${ }^{141}$ Indeed, analyses of the party's electoral victories during this period ${ }^{142}$ suggest that the far-right vote, rather than serving as a conduit for anti-immigration demands, is better understood as a protest vote against both the sociocultural changes embodied by the left-wing student movement and the political vacuum of the traditional right that resulted from the formation of the Grand Coalition. ${ }^{143}$

139 Süddeutsche Zeitung, November 15, 1966; Neue Rhein-Rubr-Zeitung, December 15, 1966; Frankfurter Rundschau, December 29, 1966.

${ }_{140}$ Hunn 2005, 188.

${ }^{141}$ Schönwälder 2001.

${ }^{142}$ Between 1966 and 1968, the NDP gained seats in seven Land parliaments and in 1969 narrowly missed entry into the Bundestag.

${ }^{143}$ Deffner 2005; Kaltefleiter 1970. 


\section{Policy Learning and the Recruttment Stop of 1973}

With the end of the recession, recruitment resumed under the new coalition government of Social Democrats and Liberals. However, politics did not fully return to its prerecession status quo because the realities of permanent settlement could no longer be ignored. By 1969 the number of guest workers had passed the prerecession mark of one million. Only one year later, numbers had close to doubled to two million. In 1973, after three more years of market-driven recruitment, the foreign population reached the four million mark. ${ }^{144}$ In many industrial regions of the country, there was no denying that years of immigrant concentration and family unification-in the absence of public infrastructure investment-had led to overcrowded housing and schools.

As a result, an interministerial consensus emerged: one and a half decades of unbridled recruitment had resulted in large-scale immigrant settlement. Whereas Swiss political elites had recognized this relationship before the commencement of recruitment in the late 1940s, it was only in the early 1970s that a comparable elite consensus was established in West Germany. Once the government had acknowledged the reality of immigrant settlement, the cabinet had to decide how to deal with the unintended consequences. The ensuing debate, which drew in various societal interests, came to be framed as a choice between rotation, on the one hand, and immigrant integration, on the other. This was the first time that the possibility of state-enforced rotation was seriously considered, both within the cabinet and in public debates. Meanwhile, a number of local immigration authorities in the Länder of Bavaria and Schleswig-Holstein had taken matters into their own hands and forcibly rotated some workers who had resided in Germany for several years. ${ }^{145}$ It is this localized practice that gave rise to the landmark ruling of the Indian case of 1978, which is at the center of Joppke's self-limited sovereignty argument.

In the rotation-versus-integration debate, the Confederation of German Employers strongly favored rotation as a tool for offsetting the fiscal and social costs of large-scale recruitment. Trade unions and the media, by contrast, countered that rotation was inhumane and would damage the country's image abroad. ${ }^{146}$ In the end, the cabinet not only decided against rotation but equally rejected the option of ceiling controls - as instituted in Switzerland - on political and diplo-

\footnotetext{
${ }^{144}$ Triadafilopoulos and Schönwälder 2006, 10.

145 Stuttgarter Zeitung, January 22, 1973; Evangelischer Pressedienst, February 20, 1973; Deutscher Bundestag, February 21, 1973.

${ }^{146}$ Schönwälder 2001.
} 
matic grounds. The Ministry of Labor expressed concerns that a ceiling system would require nationality contingents, a measure that would strain diplomatic relations with sending countries. ${ }^{147}$ Nevertheless, at the same time as the cabinet rejected rotation and ceiling controls as politically viable policy measures, interministerial disagreements prevented the adoption of a coherent integration policy. ${ }^{148}$ Instead, in June 1973 the cabinet agreed on an "action program," designed to harmonize guest worker employment with the "absorption capacity" of social infrastructures. Accordingly, recruitment would no longer be possible in locales where foreign nationals accounted for more than 12 percent (in special cases, 6 percent) of the population.

Why did West German recruitment policy in the early 1970s not follow the Swiss path of guest worker rotation? Triadafilopolous and Schönwälder have argued that the rejection of rotation as a policy measure should be understood as the result of both foreign policy constraints and "a general lack of fit with basic liberal-democratic norms." ${ }^{49}$ This article's comparative analysis, however, qualifies this assessment. While I concur that the Social Democratic-Liberal government under Willy Brandt was normatively constrained, these constraints were not, as these authors suggest, present from the beginning of recruitment but, rather, emerged in the late 1960s, when a new discourse of rotation clashed with the prior administrative practice of recruitment laissezfaire. Had rotation been an integral part of recruitment policy from the beginning, not only would guest workers have continued to make life choices based on the assumption of a short-term stay-thereby not developing a "reliance interest" on the West German state-but, from the vantage point of foreign governments, rotation would not have amounted to a retraction of previously offered benefits. In other words, two decades of uncontrolled recruitment had created a domestic and international policy lock-in that was considered too costly to break, especially given the fact that continued popular insulation continued to shield the government from concerted pressure for restrictionism.

When the West German government finally closed down recruitment, it did so under circumstances and in ways strikingly different from what occurred with the Swiss Federal Council. In November 1973, only weeks after the beginning of the oil crisis, the Labor Ministry presented a much anticipated appraisal of the country's labormarket policy. The ministry's report contended that the fiscal and so-

\footnotetext{
${ }^{147}$ Knortz 2008.

${ }^{148}$ Triadafilopoulos and Schönwälder 2006.

${ }^{149}$ Triadafilopoulos and Schönwälder 2006, 13.
} 
cial costs of recruitment no longer justified its economic benefits and concluded that "it appears doubtful that further recruitment is sensible both from a macroeconomic and socio-political perspective." 150 On November 23 the cabinet decided over the objections of employer associations to stop all recruitment immediately. While diplomatic officials utilized the developing oil crisis to justify this measure to sending countries, it is clear from the cabinet discussions of the preceding months that a recruitment stop had become only a matter of time and that the oil crisis had provided the government with welcome political capital to mitigate its diplomatic costs. Significantly, the government's decision to end recruitment was not the result of popular pressure, as in the Swiss case, but rather was the result of a process of elite learning about the long-term implications of recruitment.

Once the Brandt cabinet came to accept the fact of immigrant settlement and its concomitant social and infrastructural costs, the policy status quo was no longer acceptable. Unable to make the kind of changes (such as rotation) that would have lowered the costs of recruitment while retaining its benefits, the only way forward was to shut down the system. The suspension of recruitment in 1973 thus stands in stark contrast to the Swiss policy, where the global cap of 1970 constituted a regulatory instrument that could turn the supply of migrant workers on and off, depending on economic need. Even though the Swiss Federal Council was forced by popular pressure to scale back recruitment at a time of rapid economic growth, the tightrope walk between accommodating the labor needs of employers, on the one hand, and preventing the adoption of economically disastrous overforeignization initiatives, on the other, had facilitated a policy compromise that, in the end, allowed the government to preserve flexibility on recruitment matters.

The significance of labor-market flexibility became evident in 1975, when the oil crisis hit Switzerland hard: among the OECD countries, Switzerland shed the largest percentage of jobs-10 percent. ${ }^{151}$ But the global ceiling system allowed the government to export most of this loss by not renewing annual and seasonal work permits. As a result, of the 340,000 jobs lost, 67 percent were shed by foreigners. ${ }^{152}$ Thus, Switzerland's capacity to use economic migrants as a cyclical shock absorber as late as thirty years into recruitment clearly distinguishes the Swiss regime of migration regulation from that of West Germany.

\footnotetext{
${ }^{150}$ Cited in Knortz 2008, 175.

${ }^{151}$ Piguet 2006a, 76.

${ }_{152}$ Mahnig 1998, 180.
} 


\section{Conclusion}

It is commonly argued that advanced democracies are unable to prevent the permanent settlement of migrant workers because of the normative, legal, and economic constraints of liberalism. This article has sought to qualify these claims by examining the politics of recruitment and settlement in two of Europe's archetypical guest worker countries, Switzerland and West Germany. In doing so, three sets of findings stand as posing a challenge to our existing understanding of guest worker politics. First, the design of each recruitment system had an independent and lasting impact on settlement outcomes. Policy differences between the West German and Swiss systems resulted in crossnational variation in the pace of settlement. Second, normative and legal constraints on the enforcement of antisettlement measures were not significant in the Swiss case and mattered during the West German postrecruitment period not because these measures were considered illiberal per se but because they came to be seen as capricious in their departure from prior permissive administrative practice. In other words, the emergence of moral and legal constraints was contingent on the earlier practice of settlement laissez-faire and began to crystallize only after twenty-five years of recruitment. Third, in both countries, economic imperatives were important, but not deterministic, factors in accounting for mass recruitment. In the West German case, the timing of both the beginning and the end of recruitment is best accounted for by factors other than labor-market imperatives - foreign policy considerations in the former instance and infrastructural costs in the latter. Even in Switzerland, where market forces were least constrained, the government's decision to scale back recruitment not only ran counter to labor-market needs but also was fiercely opposed by business.

In order to account for the design of recruitment policy, then, this article has focused on two sets of variables. First, to the extent that policy design was instrumental in preventing or slowing down settlement, policy learning mattered because it provided elites with information about what policy features would minimize the risk of permanent immigration. Thus, the presence of failure-induced policy learning in the Swiss case led to the creation of a strictly regulated rotation system with a large seasonal recruitment component and few rights to permanent residence or family unification - all features that differed in the German case.

While this analysis has focused on the guest worker systems of the past, we could easily extend its argument to present-day Germany. Af- 
ter the halt to recruitment in 1973, limited labor recruitment resumed in the 1990s, but within a radically different policy framework. In an instance of contemporary failure-induced policy learning, recruitment programs are now designed to prevent settlement either by limiting permits to strictly seasonal employment - with a maximum stay of three months ${ }^{153}$ - or by issuing a limited number of permits to projecttied workers (Werkvertragsarbeitnehmer) employed by foreign firms in Germany. In a similar vein, Canada's present-day Seasonal Agricultural Workers' Program, which has been in operation since 1966, limits the employment of migrant workers to eight months and has been remarkably successful in preventing settlement over the course of nearly half a century. ${ }^{154}$

If policy learning was a particularly critical variable at the time of policy design, the question of political insulation came to matter increasingly once recruitment was under way. In the Swiss case, the government's lack of business insulation initially did not matter because the preferences of policymakers and employer associations converged. Once the public started to mobilize, however, the Federal Council found itself sandwiched between the cross-cutting pressures of organized business, on the one hand, and popular antirecruitment mobilization, on the other. The cross-cutting pressures arising from the lack of business and popular insulation, then, can account for the finding that the Federal Council progressively capped recruitment levels during times of economic boom, while retaining the system despite the oil crisis. In West Germany, by contrast, elites could operate more autonomously, and recruitment continued unconstrained for close to two decades. It was only when the government considered the infrastructural costs of recruitment too high that, insulated from popular pressure and impervious to the opposition of business, it decided to shut down the system completely.

Why did guest worker recruitment lead to large-scale settlement even in Switzerland, where the institution of rotation and the Federal Council's lack of popular insulation would have suggested otherwise? Among the range of culprits, it was the renegotiation of the Swiss-Italian agreement that sounded the death knell for rotation, because it not only lowered the bar for family unification and permanent residence for nonseasonal workers but, equally importantly, allowed seasonal workers to adjust to nonseasonal status. Significantly, the reasons that led to

\footnotetext{
153 Castles 2006.
}

${ }^{154}$ Basok 2000. 
this watershed are neither normative nor judicial but rather reflect the diplomatic struggles of a fiercely independent country to retain access to foreign labor at a time when the process of European integration turned the European Community into a preferred destination for guest workers. While we can only speculate about what would have happened had the recruitment treaty not been revised, this analysis suggests that, even in the long run, settlement would have taken place in a much slower and more limited manner than occurred in West Germany.

Preventing unwanted migrant worker settlement will always remain a policy challenge. There is no question that, in comparison with illiberal regimes such as nineteenth-century Prussia, liberal democracies are much more constrained when it comes to expelling unwanted foreign workers. Yet to argue that settlement is unavoidable and completely outside the control of governments runs the danger of misinterpreting the West German experience, as well as ignoring the postwar Swiss experience. The proliferation of new temporary migrant worker programs over the past two decades suggests that arguments about the normative constraints of liberal state elites may be overblown, even in the case of the "semisovereign"155 state par excellence, Germany. Incorporating the policy lessons of the guest worker era, rotation is now a fundamental feature of low-skilled migrant worker recruitment across Western Europe-despite the "self-limited" sovereignty of these states.

\section{REFERENCES}

Almond, Gabriel A., and Sidney Verba, eds. 1989. The Civic Culture: Political Attitudes and Democracy in Five Nations. New York, N.Y.: Sage.

Argast, Regula. 2007. Staatsbürgerschaft und Nation: Ausschliessung und Integration in der Schweiz, 1848-1933 [Nationality and Nation: Exclusion and Integration in Switzerland, 1848-1933]. Göttingen, Germany: Vandenhoeck \& Ruprecht. . 2009. "An Unholy Alliance: Swiss Citizenship between Local Legal Tradition, Federal Laissez-Faire, and Ethno-National Rejection of Foreigners, 1848-1933." European Review of History 16, no. 4: 503-21.

Aubert, Jean-François. 1978. "Switzerland." In David Butler and Austin Ranney, eds., Referendums: A Comparative Study of Practice and Theory. Washington, D.C.: American Enterprise Institute for Public Policy Research.

Bade, Klaus J. 1982. "Kulturkampf' auf dem Arbeitsmarkt: Bismarcks 'Polenpolitik' 1885-1890.” In Olaf Pflanze, ed., Innenpolitische Probleme des BismarckReiches [Domestic Problems of the Bismarck Empire]. Munich, Germany: R. Oldenbourg.

${ }^{155}$ Katzenstein 1987b. 
Baker, Kendrick L., Russell J. Dalton, and Kai Hildebrandt. 1981. Germany Transformed: Political Culture and the New Politics. Cambridge, Mass.: Harvard University Press.

Basok, Tanya. 2000. "He Came, He Saw, He ... Stayed: Guest Worker Programmes and the Issue of Non-Return." International Migration 38, no. 2: 216-38.

Baumeister, Roy, Ellen Bratslavsky, Catrin Finkenauer, and Kathleen Vohs. 2001. "Bad Is Stronger Than Good." Review of General Psychology 5, no. 4: 323-70.

Bendix, John. 1990. Importing Foreign Workers: A Comparison of German and American Policy. New York, N.Y.: Peter Lang.

Bethlehem, Siegfried. 1982. Heimatvertreibung, DDR-Flucht, Gastarbeiterzuwanderung: Wanderungsströme und Wanderungspolitik in der Bundesrepublik Deutschland [Expulsion, Escape from the GDR, and Guestworker Immigration: Immigration Flows and Immigration Politics in the Federal Republic of Germany]. Stuttgart, Germany: Klett-Cotta.

Blaas, Wolfgang. 1992. "The Swiss Model: Corporatism or Liberal Capitalism.” In Jukka Pakkarinen, Matti Pohjol, and Bob Rowthorn, eds., Social Corporatism: A Superior Economic System? Oxford, UK: Oxford University Press.

Boscardin, Lucio. 1962. Die italienische Einwanderung in die Schweiz mit besonderer Berücksichtigung der Jabre 1946-1959 [Italian Immigration to Switzerland with a Particular Focus on the Years 1946-1959]. Zurich, Switzerland: Polygraphischer Verlag.

Brubaker, Rogers. 1992. Citizenship and Nationhood in France and Germany. Cambridge, Mass.: Harvard University Press.

Buomberger, Thomas. 2004. Kampf gegen unerwünschte Fremde: Von James Schwarzenbach bis Christoph Blocher [Fight against Unwanted Strangers: From James Schwarzenbach to Christoph Blocher]. Zurich, Switzerland: Orell Füssli.

Castles, Steven. 1985. "The Guests Who Stayed: The Debate on 'Foreigners Policy' in the German Federal Republic." International Migration Review 19, no. 3: $517-34$.

- 2006. "Guestworkers in Europe: A Resurrection?” International Migration Review 40, no. 4: 741-66.

Cerutti, Mauro. 2005. "La Politique Migratoire de la Suisse, 1945-1970." In Hans Mahnig, ed., Histoire de la Politique de Migration, d'Asile et d'Integration en Suisse Depuis 1948 [Political History of Migration, Asylum, and Integration to Switzerland since 1948]. Zurich, Switzerland: Seismo.

Cornelius, Wayne A., Philip L. Martin, and James F. Hollifield, eds. 2004. Controlling Immigration: A Global Perspective, 2nd ed. Stanford, Calif.: Stanford University Press.

Deffner, Ingo. 2005. Die Reaktionen der Parteien und der Öffentlichkeit auf die Wablerfolge der NDP in der zweiten Hälfte der 60er Jahre [Responses by Political Parties and the Public to the Electoral Victories of the NDP in the Latter Half of the 1960s]. Norderstedt, Germany: Grin Verlag.

Fetzer, Joel S. 2000. Public Attitudes toward Immigration in the United States, France, and Germany. New York, N.Y.: Cambridge University Press.

Freeman, Gary P. 1995 "Modes of Immigration Politics in Liberal Democratic States.” International Migration Review 19, no. 4: 881-913. 
Gonzalez-Ferrer, Amparo. 2007. "The Process of Family Reunification among Original Guest-Workers in Germany." Zeitschrift für Familienforschung 19, no. 1: 10-33.

Gruner, Erich. 1956. Die Wirtschaftsverbände in der Demokratie [The Economic Associations of Democracy]. Erlenbach-Zürich, Switzerland: Rentsch.

Hainmueller, Jens, and Michael J. Hiscox. 2007. "Educated Preferences: Explaining Attitudes toward Immigration in Europe." International Organization 61, no. 2: 399-442.

Hall, Peter A. 1993. "Policy Paradigms, Social Learning, and the State: The Case of Economic Policymaking in Britain." Comparative Politics 25, no. 3: 275-96.

Heclo, Hugh. 1974. Modern Social Politics in Britain and Sweden: From Relief to Income Maintenance. New Haven, Conn.: Yale University Press.

Herbert, Ulrich. 2001. Geschichte der Ausländerpolitik in Deutschland: Saisonarbeiter, Zwangsarbeiter, Gastarbeiter, Flüchtlinge [History of Foreigner Policy in Germany: Seasonal Workers, Forced Laborers, Guestworkers, Refugees]. Munich, Germany: C. H. Beck.

Hollifield, James F. 1992. Immigrants, Markets, and States. Cambridge, Mass.: Harvard University Press.

Hunn, Karin. 2005. Nächstes Jahr kehren wir zurück ... Die Geschichte der türkischen "Gastarbeiter" in der Bundesrepublik [Next Year We Will Go Back ... The History of Turkish "Guestworkers" in the Federal Republik]. Göttingen, Germany: Wallstein.

Immergut, Ellen M. 1992. Health Politics: Interests and Institutions in Western Europe. Cambridge, UK: Cambridge University.

Jacoby, Nicole. 2003. "America's De Facto Guest Workers: Lessons from Germany's Gastarbeiter for U.S. Immigration Reform.” Fordham International Law Journal 27, no. 4: 1568-1662.

Janmatt, Jan German. 2006. "Civic Culture in Western and Eastern Europe." European Journal of Sociology 47, no. 3: 363-93.

Joppke, Christian. 1998. "Why Liberal States Accept Unwanted Immigration." World Politics 50, no. 2 (January): 266-93.

Kaltefleiter, Werner. 1970. "The Impact of the Election of 1969 and the Formation of the New Government on the German Party System." Comparative Politics 2, no. 4: 593-60.

Kamber, Esther, and Mario Schranz. 2000. "Die Wahrnehmung des Fremden in deutsch-schweizerischen Medien.” In Hans-Joachim Hoffmann-Nowotny, ed., Das Fremde in der Schweiz: Ergebnisse soziologischer Forschung [Otherness in Switzerland: Results of Sociological Research]. Zurich, Switzerland: Seismo Verlag.

Katzenstein, Peter J. 1987a. Corporatism and Change: Austria, Switzerland, and the Politics of Industry. Ithaca, N.Y.: Cornell University Press.

- 1987b. Policy and Politics in West Germany: The Growth of a Semisovereign State. Philadelphia, Pa.: Temple University Press.

Kessler, Alan, and Gary Freeman. 2005. "Public Opinion in the EU on Immigration from Outside the Community." Journal of Common Market Studies 43, no. 4: 825-50.

Kielmansegg, Peter Graf. 1990. "The Basic Law: Response to the Past or Design for the Future?" Occasional Paper 1. Washington, D.C.: German Historical Institute. 
Knortz, Heike. 2008. Diplomatische Tauschgeschäfte: Gastarbeiter in der westdeutschen Diplomatie und Beschäftigungspolitik 1953-1973 [Diplomatic Barter Trade: Guestworkers and West German Diplomacy and Labor Politics 19531973]. Cologne, Germany: Böhlau.

Kriesi, Hanspeter. 1982. "The Structure of the Swiss Political System.” In Gerhard Lehmbruch and Philippe C. Schmitter, eds., Patterns of Corporatist Policymaking. London, UK: Sage.

- 1995. Le système politique Suisse [The Swiss Political System]. Paris, France: Economica.

Kühne, Peter. 2000. "The Federal Republic of Germany: Ambivalent Promotion of Immigrants' Interests." In Rinus Penninx and Judith Roosbald, eds., Trade Unions, Immigration and Immigrants in Europe, 1960-1993. New York, N.Y.: Berghahn.

Kury, Patrick. 2003. Über Fremde reden: Überfremdungsdiskurs und Ausgrenzung in der Schweiz, 1900-1945 [Talking about Strangers: Overforeignization Discourse and Exclusion in Switzerland, 1900-1945]. Zurich, Switzerland: Chronos.

Lahav, Gallya. 2004. Immigration and Politics in the New Europe: Reinventing Borders. New York, N.Y.: Cambridge University Press.

Lucassen, Leo. 2001. "A Many-headed Monster: The Evolution of the Passport System in the Netherlands and Germany in the Long Nineteenth Century." In Jane Caplan and John Torpey, eds., Documenting Individual Identity: The Development of State Practices in the Modern World. Princeton, N.J.: Princeton University Press.

Mahnig, Hans, and Etienne Piguet. 2004. "Die Immigrationspolitik der Schweiz von 1948 bis 1998." In Hans-Rudolph Wicker, Rosita Fibbi, and Werner Haug, eds., Migration und die Schweiz [Migration and Switzerland], 2nd ed. Zurich, Switzerland: Seismo.

Mahnig, Hans, and Andreas Wimmer. 2003. "Integration without Immigrant Policy: The Case of Switzerland.” In Friedrich Heckmann and Dominique Schnapper, eds., The Integration of Immigrants in European Societies: National Differences and Trends of Convergence. Stuttgart, Germany: Lucius \& Lucius.

Martin, Philip L. 2001. "There Is Nothing More Permanent Than Temporary Foreign Workers.” Backgrounder. Washington, D.C.: Center for Immigration Studies.

Martin, Philip L., and Mark J. Miller. 1980. "Guestworkers: Lessons from Western Europe." Industrial and Labor Relations Review 33, no. 3: 315-30.

May, Peter J. 1992. "Policy Learning and Failure." Journal of Public Policy 12, no. 4: 331-54.

Money, Jeannette. 1999. Fences and Neighbors: The Political Geography of Immigration Control. Ithaca, N.Y.: Cornell University Press.

Neidhart, Leonhard. 1970. Plebiszit und pluralitäre Demokratie: eine Analyse der Funktion des schweizerischen Gesetzesreferendums [Plebiscite and Pluralist Democracy: Analyzing the Function of the Swiss Legislative Referendum]. Bern, Switzerland: Francke.

Neuman, Gerald L. 1990. "Immigration and Judicial Review in the Federal Republic of Germany." New York University Journal of International Law and Politics 23, no. 35: 35-85. 
Niederberger, Josef Martin. 1982. "Die politisch-administrative Regelung von Einwanderung und Aufenthalt von Ausländern in der Schweiz: Strukturen, Prozesse, Wirkungen.” In Hans-Joachim Hoffmann-Nowotny and Karl-Otto Hondrich, eds., Ausländer in der Bundesrepublik Deutschland und in der Schweiz: Segregation und Integration [Foreigners in the Federal Republic of Germany and in Switzerland: Segregation and Integration]. Frankfurt am Main, Germany: Campus Verlag.

Niehr, Thomas. 2004. Der Streit um Migration in der Bundesrepublik Deutschland, der Schweiz und Österreich: Eine vergleichende diskursgeschichtliche Untersuchung [The Fight about Migration in the Federal Republic of Germany, Switzerland, and Austria: A Comparative Historical Discourse Analysis]. Heidelberg, Germany: Winter.

Pagenstecher, Cord. 1993. "Rotationsprinzip und Rückkehrorientierung im Einwanderungsprozess: 'Gastarbeit' in der Bundesrepublik Deutschland.” M.A. thesis, Freie Universität Berlin.

Pierson, Paul. 1993. "When Effect Becomes Cause: Policy Feedback and Political Change." World Politics 45, no. 4 (July): 595-628.

Piguet, Etienne. 2006a. "Economy versus the People? Swiss Immigration Policy between Economic Demand, Xenophobia, and International Constraint." In Marco G. Giugni and Florence Passy, eds., Dialogues on Migration Policy. Lanham, Md.: Lexington Books.

- 2006b. Einwanderungsland Schweiz: FünfJahrzehnte halb geöffnete Grenzen [Switzerland, Country of Immigration: Five Decades of Half Open Borders]. Bern, Switzerland: Haupt.

Reichert, Joshua S., and Douglas S. Massey. 1982. "Guestworker Programs: Evidence from Europe and the United States and Some Implications for U.S. Policy." Population Research and Policy Review 1, no. 1: 1-17.

Reutter, Werner. 2001. "Verbände zwischen Pluralismus, Korporatismus und Lobbyismus.” In Werner Reutter and Peter Rütters, eds., Verbände und Verbandsysteme in Westeuropa [Associations and Association Networks in Western Europe]. Opladen: Leske \& Budrich.

Rohner, Andreas. 2011. "Direct Democracy in the German Länder: History, Institutions, and (Mal)Functions." C2D Working Paper Series 38. Zurich, Switzerland: Centre for Research on Direct Democracy.

Rose, Richard. 1993. Lesson-drawing in Public Policy: A Guide to Learning across Time and Space. London, UK: Chatham House.

Rothmayr, Christine. 2001. "Towards the Judicialisation of Swiss Politics?” West European Politics 24, no. 2: 77-94.

Sassen, Saskia. 1996. Losing Control: Sovereignty in an Age of Globalization. New York, N.Y.: Columbia University Press.

Schmitter Heisler, Barbara. 2000. "Trapped in the Consociational Cage: Trade Unions and Immigration in Switzerland.” In Rinus Penninx and Judith Roosbald, eds., Trade Unions, Immigration and Immigrants in Europe, 1960-1993. New York, N.Y.: Berghahn.

Schönwälder, Karin. 2001. Einwanderung und ethnische Pluralität [Immigration and Ethnic Plurality]. Essen, Germany: Klartext.

Seol, Dong-Hoon, and John D. Skrentny. 2009. "Why Is There So Little Migrant Settlement in East Asia?” International Migration Review 43, no. 3: 578-620. 
Sheldon, George. 2007. Migration, Integration und Wachstum: Die Performance und wirtschaftliche Auswirkung der Ausländer in der Schweiz [Migration, Integration and Growth: The Performance and Economic Impact of Foreigners in Switzerland]. Basel, Switzerland: Forschungsstelle für Arbeitsmarkt- und Industrieökonomie.

Sniderman, Paul M., Louk Hagendoorn, and Markus Prior. 2004. "Predisposing Factors and Situational Triggers: Exclusionary Reactions to Immigrant $\mathrm{Mi}^{-}$ norities." American Political Science Review 98, no. 1: 35-49.

Soroka, Stuart N. 2006. "Good News and Bad News: Asymmetric Responses to Economic Information.” Journal of Politics 68, no. 2: 372-85.

Torpey, John. 2000. The Invention of the Passport: Surveillance, Citizenship, and the State. Cambridge, UK: Cambridge University Press.

Vuilleumier, Marc. 1992. Flüchtlinge und Immigranten in der Schweiz: Ein historischer Überblick [Refugees and Immigrants in Switzerland: A Historical Overview]. Zurich, Switzerland: Pro Helvetia.

Triadafilopoulos, Triadafilos, and Karen Schönwälder. 2006. "How the Federal Republic Became an Immigration Country: Norms, Politics, and the Failure of West Germany's Guestworker System." German Politics and Society 24, no. 3: $1-19$.

Wilson, James Q. 1980. “The Politics of Regulation.” In James Q. Wilson, ed., The Politics of Regulation. New York, N.Y.: Basic Books.

\section{Archival Sources}

\section{Politisches Archiv des Auswärtigen Amtes [Political Archive} of the Ministry of Foreign Affairs], Berlin, Germany

Auswärtiges Amt. March 20,1972. Memorandum by Referat V6 to Referat IA4 (V6 -80.55)."Aussenpolitische Auswirkungen der Beschäftigung ausländischer Arbeitnehmer in der BRD.” B85, 1031.

Deutscher Bundestag. February 17, 1955. Stenographischer Bericht, 66. Sitzung.

Deutscher Bundestag. February 21, 1973. Anlage zum Protokoll der 3. Sitzung des Innenausschusses. B85, 1031.

Parlamentsarchiv des Deutschen Bundestages [Parliamentary Archive of the German Bundestag], Berlin, Germany

Bildzeitung. March 31, 1966. "Gastarbeiter fleissiger als deutsche Arbeiter?"

Evangelischer Pressedienst. February 20, 1973. "Proteste gegen die 'Rotation' von Gastarbeitern."

Frankfurter Rundschau. December 20, 1954. "Storch: Kein Facharbeitermangel. Ausländische Arbeitskräfte sollen nicht vor 1957 kommen.”

Frankfurter Rundschau. February 27, 1961. "Mit Kind und Kegel ins Ruhrgebiet: Ausländische Bergleute holen nach einjähriger Trennung ihre Familien nach.”

Frankfurter Rundschau. December 29, 1966. "Gewerkschaft nimmt Gastarbeiter in Schutz."

Industrie-Kurier. November 19, 1955. "Anwerbung von Italienern ist gesichert: Deutsche Kommission geht nach Mailand.”

Neue Rhein-Ruhr-Zeitung. December 15, 1966. "Figgen: Verträge der Gastarbeiter überprüfen.” 
Neue Zürcher Zeitung. November 13, 1946. "Ausländische Arbeitskräfte und Überfremdung."

Neue Zürcher Zeitung. December 22, 1955. "Italienische Arbeiter für Westdeutschland."

Neue Zürcher Zeitung. November 21, 1960. "Der Aufenthalt ausländischer Arbeitskräfte."

Rhein-Zeitung. December 14, 1954. "Kommen Italienische Arbeiter? Die Verhandlungen haben begonnen."

Stuttgarter Zeitung. January 22, 1973. "Sesshaftwerden von Gastarbeitern unerwünscht."

Süddeutsche Zeitung. December 21, 1954. "Fremdarbeiter nur im Bedarfsfall."

Süddeutsche Zeitung. November 15, 1966. "Langer Kündigungsschutz nur für wenige Gastarbeiter."

\section{Schweizerisches Bundesarchiv [Swiss Federal Archive],} BERn, SwitZERLAND

Bundesamt für Industrie, Gewerbe und Arbeit. March 31, 1953. Memorandum. "Vorsorgliche Massnahmen gegen die Überfremdung des Arbeitsmarktes." E2001E 1970_217, Bd. 205.

Bundesamt für Industrie, Gewerbe und Arbeit. 1964. Das Problem der ausländichen Arbeitskräfte: Bericht der Studienkommission für das Problem der ausländischen Arbeitskräfte. BIGA: Bern.

Eidgenössisches Justiz- und Polizeidepartement. December 12, 1956. Memorandum. "Kreisschreiben an die Polizeidirektionen der Kantone." E2001 E1970_217 Bd 205.

Eidgenössische Fremdenpolizei. December 28, 1950. Letter to Dr. Heinrich Rothmund, E3/202, "Saisonarbeiter im Baugewerbe. Widerruf von Aufenthaltsbewilligungen.” E2001E 1967_113 Bd.368.

Ständerat. December 8, 1964. Amtliches Bulletin der Bundesversammlung: 9104 Italienische Arbeitskräfte in der Schweiz. Bern: Verbandsdruckerei.

\section{Schweizerisches Sozialarchiv [Swiss Social Archive], Zurich, SWITZERLAND}

Schweizerische Arbeitgeber-Zeitung. June 20, 1947. "Fremdarbeiter in der Schweiz."

Schweizerischer Metall- und Uhrenarbeiterverband. June 6, 1946. Internal memorandum. SMUV 05D-0004, Zirkulare.

Schweizerischer Metall- und Uhrenarbeiterverband. August 11, 1955. "Bericht über das Fremdarbeiterproblem in der Maschinen- und Metallindustrie." SMUV 05D-0015, 1947-1963.

Schweizerischer Metall- und Uhrenarbeiterverband. 1962. "SMUV Vortagswoche Oktober 1961.” SMUv 10B-0008 2/1961. 